\title{
Composition and natural history of a Cerrado snake assemblage at Itirapina, São Paulo state, southeastern Brazil
}

\author{
Ricardo Jannini Sawaya ${ }^{1,2,4}$, Otavio Augusto Vuolo Marques $^{2} \&$ Marcio Martins $^{3}$ \\ ${ }^{1}$ Programa de Pós-Graduação em Ecologia, Departamento de Zoologia e Museu de História Natural, \\ Instituto de Biologia, Universidade Estadual de Campinas - UNICAMP, \\ CP 6109, CEP 13083-970, Campinas, SP, Brazil \\ ${ }^{2}$ Laboratório Especial de Ecologia e Evolução, Instituto Butantan, \\ Av. Doutor Vital Brasil, 1500, CEP 05503-900, São Paulo, SP, Brazil \\ ${ }^{3}$ Departamento de Ecologia, Instituto de Biociências, Universidade de São Paulo - USP, \\ Rua do Matão, Travessa 14, $n^{\circ}$ 321, CEP 05508-090, São Paulo, São Paulo, Brazil \\ ${ }^{4}$ Corresponding author: Ricardo Jannini Sawaya, e-mail: sawaya@butantan.gov.br
}

SAWAYA, R.J., MARQUES, O.A.V. \& MARTINS, M. 2008. Composition and natural history of a Cerrado snake assemblage at Itirapina, São Paulo state, southeastern Brazil. Biota Neotrop. 8(2): http://www. biotaneotropica.org.br/v8n2/en/abstract?inventory+bn01308022008.

\begin{abstract}
Neotropical snake assemblages present high species richness and complex structures. The Cerrado is the second largest biome in Brazil, and was included among the 25 World's biodiversity hotspots. In southeastern Brazil, the remnant Cerrado areas have suffered intense destruction, and presently less than $2 \%$ of Cerrado natural vegetation remain in São Paulo state. Virtually no detailed study on Cerrado snakes was carried out in this region. The Itirapina region has one of the last well preserved remnants of open cerrado in São Paulo state. Our purpose in this work was the study of natural history and composition of the Cerrado snakes of Itirapina region. We performed an extensive field sampling combining six sampling methods in Estação Ecológica de Itirapina and disturbed Cerrado areas in its surroundings (municipalities of Itirapina and Brotas), during 101 trips throughout 43 months, between September 1998 and March 2002, corresponding to 446 days of field sampling. We also collected additional data from museum specimens housed in scientific collections. We present data on size, general abundance, habitat and macrohabitat use, daily and seasonal activity, feeding, reproduction, and defense. We also compared the Itirapina snake assemblage with nine snake assemblages of Brazil, from Amazonia, Atlantic Forest, Cerrado, and other open habitats. We recorded a total of 36 snake species among 755 individuals found in the field and six records from scientific collections and literature, belonging to 25 genera and five families. The snake assemblage comparisons indicate that the Cerrado has its own identity regarding the snake composition. Although small (about 2,300 ha), the Estação Ecológica de Itirapina encompasses well preserved and representative Cerrado physiognomic forms, which harbors a rich and typical Cerrado snake fauna. The occurrence of some species only inside the reserve also indicates that the Estação Ecológica de Itirapina is of fundamental importance to the maintenance of Cerrado biodiversity. Keywords: biodiversity, natural history, Squamata, Serpentes, Cerrado, Itirapina, São Paulo, Brazil.
\end{abstract}

SAWAYA, R.J., MARQUES, O.A.V. \& MARTINS, M. 2008. Composição e história natural das serpentes de Cerrado de Itirapina, São Paulo, sudeste do Brasil. Biota Neotrop. 8(2): http://www.biotaneotropica.org.br/ v8n2/pt/abstract?inventory+bn01308022008.

Resumo: As taxocenoses de serpentes neotropicais apresenta $m$ alta riqueza de espécies e estruturas complexas. O Cerrado é o segundo maior bioma do Brasil e foi incluído entre os 25 hotspots globais de biodiversidade. No sudeste do Brasil, as áreas remanescentes de Cerrado têm sofrido intensa destruição, e atualmente restam menos de $2 \%$ da vegetação natural de Cerrado no estado de São Paulo. Praticamente nenhum estudo detalhado sobre serpentes do Cerrado foi realizado nesta região. A região de Itirapina apresenta um dos últimos remanescentes bem preservados de cerrado aberto no estado de São Paulo. Nosso objetivo neste trabalho foi o estudo da história natural e composição das serpentes de Cerrado da região de Itirapina. Nós realizamos uma amostragem de campo extensiva combinando seis métodos de amostragem na Estação Ecológica de Itirapina e áreas alteradas de Cerrado nas proximidades (municípios de Itirapina e Brotas), em 101 viagens durante 43 meses, entre setembro de 1998 e março de 2002, o que correspondeu a 446 dias de amostragem de campo. Também coletamos dados adicionais a partir de espécimes de coleções científicas. Apresentamos dados sobre tamanho, abundância geral, uso do ambiente e substrato, atividade diária e sazonal, dieta, reprodução e defesa. Também comparamos a taxocenose de serpentes de Itirapina com nove taxocenoses de serpentes do Brasil, incluindo a Amazônia, Mata Atlântica, Cerrado e outras formações abertas. Registramos na região de Itirapina 36 espécies de serpentes entre 755 indivíduos encontrados no campo e seis registros de coleções científicas e literatura, pertencentes a 25 gêneros de cinco famílias. As comparações entre taxocenoses indicam que o Cerrado apresenta uma identidade própria em relação à composição de espécies de serpentes. Apesar de limitada a um pequeno fragmento (cerca de 2.300 ha), a Estação Ecológica de Itirapina apresenta fisionomias conservadas e representativas de Cerrado, que abrigam uma fauna de serpentes rica e típica do Cerrado. A ocorrência de algumas espécies apenas no interior da reserva também indica que a Estação Ecológica de Itirapina é de importância fundamental para a manutenção da biodiversidade do Cerrado.

Palavras-chave: biodiversidade, história natural, Squamata, Serpentes, Cerrado, Itirapina, São Paulo, Brasil. 


\section{Introduction}

Natural history describes where the organisms are and what they do in their habitats, including the interactions among them (Greene 1994). Thus, natural history allows the recognition of patterns and their causal mechanisms, being the basic information of ecology (Ricklefs 1990). It is also fundamental to other areas of biology such as evolutionary biology and conservation (Greene \& Losos 1988, Hillis 1995).

Neotropical snake assemblages present high species richness and complex structures, related to high diversity of resource use, activity patterns, reproduction, and morphology (e.g., Duellman 1989, 1990, Zimmermann \& Rodrigues 1990, Cadle \& Greene 1993, Martins \& Oliveira 1998). However, our understanding about the structure of Neotropical snake assemblages is still incipient. Furthermore, most studies on snake assemblages in the Neotropics have been conducted in forested habitats (e.g., Cunha \& Nascimento 1978, Dixon \& Soini 1986, Zimmermann \& Rodrigues 1990, Martins \& Oliveira 1998, Marques 1998, Hartmann 2005, Bernarde \& Abe 2006), making comparison of snake assemblages in the wide variety of biomes of the region difficult (Strüssmann \& Sazima 1993).

Even basic information on snakes in Brazil are scarce or unavailable for most species (Sazima \& Haddad 1992), and relatively few studies focusing on snake assemblages exist (Amazon: Martins 1994, Bernarde \& Abe 2006; Caatinga: Vitt \& Vangilder 1983; Pampa: Cechin 1999; Pantanal: Strüssmann \& Sazima 1993; Araucaria Forests: Di-Bernardo 1998; Atlantic Forest: Marques 1998, Hartmann 2005). Studies including or focusing on open habitats are also rare in Brazil. For the Caatinga of northeastern Brazil, Vanzolini et al. (1980) presented data on species composition, taxonomy, and distribution, including fragmented information on the ecology of lizards and snakes; in another study, Vitt \& Vangilder (1983) focused on the snake assemblage of Exu (Pernambuco state), comparing habits, activity, diet, reproduction, and morphology. For the Pantanal of western Brazil (Mato Grosso state), Strüssmann \& Sazima (1993) provided data on species composition, habitat, macrohabitat use, activity, and diet of snakes, and made comparisons with other assemblages from open and forested habitats. For the Araucaria forests and associated grasslands of southern Brazil (Rio Grande do Sul state), Di-Bernardo (1998) provided data on diversity, habitat use, activity, growth, diet, and reproduction of snakes. For a grassland area of Pampa in southern Brazil (Rio Grande do Sul state), Cechin (1999) provided data on diversity, comparisons among sampling methods, activity, diet, and habitat use of snakes, and discussed the factors that may be responsible for the community structure observed. For the Cerrado, Carvalho \& Nogueira (1998) provided a snake species list from the Cerrado remnants of an urban area of Cuiabá (Mato Grosso state), including data on relative abundance, macrohabitat use, diel activity, and diet; Strüssmann (2000) provides information on the herpetofauna of the Manso river (Mato Grosso state); França \& Araújo (2006) describe the faunal composition and analyse the conservation status of the cerrado snakes from Distrito Federal, central Brazil; Colli et al. (2002) present a general species list and discuss the character of the Cerrado herpetofauna; and Costa et al. (2007) present an updated Squamate reptile list for the Cerrado and analyse richness and its environmental and climatic associations. The most recent evidence (Costa et al. 2007) shows that species richness for cerrado Squamate reptiles was underestimated even in recent compilations (e.g. Colli et al. 2002).

The Cerrado is the second largest biome in Brazil, with approximately two million square kilometers, which corresponds to about $23 \%$ of the total country area (Ratter et al. 1997). The Brazilian Cerrado was included among the 25 world's biodiversity hotspots because of its large number of endemic species and high levels of human disturbance (Myers et al. 2000). But even basic information on natural history of the Cerrado herpetofauna are virtually unavailable (Colli et al. 2002). In southeastern Brazil, the areas covered by cerrado physiognomic forms have suffered intense destruction by agricultural practice and cattle raising, and presently less than $2 \%$ of the original cerrado vegetation remains in São Paulo state (Kronka et al. 1993). Thus, studies that provide information on the native fauna of those remnants are urgent and of great importance for conservation. Virtually no detailed study on Cerrado snakes was carried out in this region. The information available on snakes in those areas are limited to species lists, taxonomic comments, and information on the biology of some species (e.g., Vanzolini 1948, Costa 1979, Brites \& Bauab 1988).

It is impossible to define conservation strategies without basic knowledge on ecosystems. The study of biodiversity, focused on species composition, distribution, and/or community structure, is among the basic goals of the Global Strategy for Biodiversity (Wilson 1992). Natural history and ecological information required for conservation are available for only a small fraction of animal species, generally those large and common, or relatively easy to study (Greene 1994). The Itirapina region encompasses some of the last remnants of open Cerrado formations in São Paulo state. Therefore, it is an appropriate locality for the study of composition, natural history, and ecology of Cerrado snakes in southeastern Brazil. Our purpose in this work was to study the natural history and composition of the Cerrado snakes of Itirapina region. We provide basic knowledge that can help the understanding of how Cerrado snake assemblages are structured, and it can be used in management and conservation practices for the remnant and highly fragmented Cerrado areas in São Paulo state.

\section{Material and Methods}

\section{Study area}

We collected most of the data in Estação Ecológica de Itirapina (ca. 2,300 ha), located in the municipalities of Itirapina and Brotas

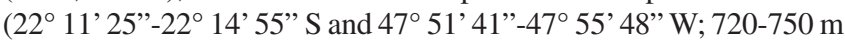
elevation). The reserve is covered by well preserved, natural Cerrado vegetation, mainly campo limpo (grasslands), campo sujo (grasslands with scattered shrubs), campo cerrado (grasslands with scattered shrubs and trees), gallery forests, and marshes. The climate of this region is mesothermic with a marked dry season from April to September, and a wet season from October to March. Occasional frosts occurred in winter, usually in June and July. Detailed information on EEI vegetation, climate, and soil, as well as color pictures of the Cerrado physiognomic forms, are available in Brasileiro et al. (2005).

Besides the reserve, we sampled disturbed Cerrado areas surrounding the reserve, which include agriculture and cattle raising, pine and eucalyptus plantations, and a dam. We also sampled additional fragments of Cerrado close to the reserve (including an area of cerrado sensu strictu), in the municipalities of Itirapina and Brotas. The maximum distance from those areas to the reserve is approximately $10 \mathrm{~km}$.

\section{Fieldwork}

Snake sampling was carried out from September 1998 to March 2002. In these 43 months we made 101 trips to Itirapina, corresponding to 446 days of fieldwork. Sampling was divided in two phases: 46 irregularly spaced trips were made from September 1998 to February 2000 (113 days of fieldwork), and 55 regular fieldtrips (two trips every month, each trip six days long) were made from February 2000 to March 2002 (333 days of fieldwork). 
We used six methods for the snake sampling in the field:

1) Pitfall traps with drift fence (sensu Greenberg et al. 1994, Cechin \& Martins 2000). We installed three units of pitfall traps with drift fence in three vegetation types (see Brasileiro et al. 2005): campo cerrado, campo sujo, and along the border of gallery forest (beside the campo sujo; the frequent floodings of gallery forest made the installation of pitfall traps inside these forests impossible). Each unit of pitfall corresponded to two $45 \mathrm{~m}$ trap lines, $100 \mathrm{~m}$ from each other. Each line had four $100 \mathrm{~L}$ plastic buckets every $15 \mathrm{~m}$, connected by a $60 \mathrm{~cm}$ high plastic net fence. The buckets were perforated on the bottom to avoid the accumulation of rain water. The fence was buried $10 \mathrm{~cm}$ into the soil. It was attached to wooden stakes, and installed passing $10 \mathrm{~cm}$ depth from the top border of each bucket (see Figure 1 of Cechin \& Martins 2000). A piece of styrofoam $(25 \times 24 \times 5 \mathrm{~cm})$, supported by wood sticks, and a small water plate were placed inside each bucket to provide moisture and shelter to prevent dehydration of the snakes. We installed a total of nine trap units (18 lines, 72 buckets, and $810 \mathrm{~m}$ of fences). We sampled the pitfall traps twice a month in periods of five consecutive days during the regular sampling. Thus, we sampled a total of 293 non-consecutive days of pitfall traps, corresponding to 21,096 bucket-days;

2) Coverboards (Parmelee \& Fitch 1995) were artificial shelters for snakes, corresponding to a $1.1 \times 1.1 \mathrm{~m}$ square made of wood, four or six mm thick, placed on the ground after clearing the vegetation. We installed a total of 72 coverboards, each of them $5 \mathrm{~m}$ from each pitfall trap bucket, perpendicular to the drift fence. We inspected each coverboard on the same day as pitfall traps, including the day we opened the traps. We sampled 143 non-consecutive days of coverboards, corresponding to 10,296 inspections;

3) Time constrained search (sensu Campbell \& Christman 1982, Scott et al. 1989, Martins \& Oliveira 1998) consisted of walking slowly, searching for snakes in all visual accessible microhabitats. The sampling effort and encounter rate of snakes were based on person-hours of search (Martins \& Oliveira 1998). Each snake found was captured by hand, tongs, or hooks, and venomous species were handled with plastic tubes. We recorded on field forms data on behavior, morphology, capture location, and other information (see Sawaya 2004). The defensive behavior of snakes was recorded during the approach of an observer and/or the specimen handling, and the number of observations of each behavior refers to the number of different individuals that showed that behavior. We performed 899.9 person-hours of searching in different vegetation types in the EEI and disturbed areas in its surroundings;

4) Road sampling was the sighting of snakes on paved and unpaved roads both inside the reserve and in its surroundings. We used the unpaved roads commonly used for the pitfall trap inspection, and additional unpaved roads for this purpose, besides roads outside the reserve. The sampling effort was quantified in $\mathrm{km}$ covered, and usually the vehicle speed was $20-30 \mathrm{~km} / \mathrm{h}$, with a maximum of $40 \mathrm{~km} / \mathrm{h}$. We sampled $3,580.9 \mathrm{~km}$ of roads;

5) Incidental encounters corresponded to the sighting of snakes alive or dead during other activities than the sampling with the above methods, like moving among sampling areas. We included specimens found inside and outside the reserve, as well as those found in its vicinity and access roads, and snakes found beside the fences of the pitfall traps. The sampling effort of incidental encounters was considered as the total number of days of fieldwork, that corresponded to 446 days; and

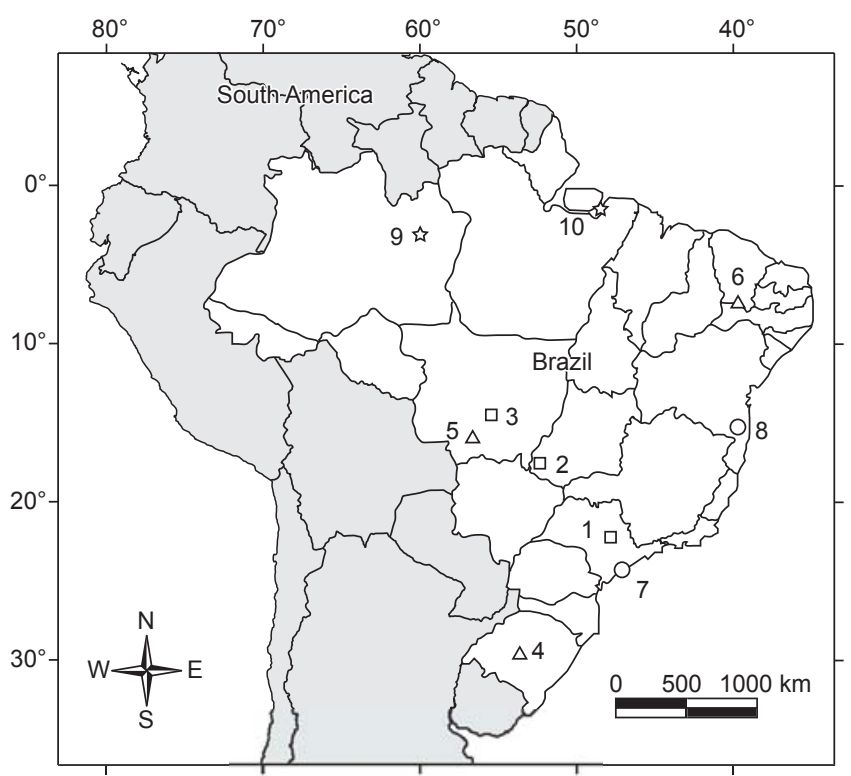

Figure 1. Cerrado (ם), other open habitats (Pantanal, Pampa e Caatinga; $\Delta$ ), Atlantic Forest (O), and Amazon («) localities used for comparison among Brazilian snake assemblages: 1) Itirapina (São Paulo state); 2) Parque Nacional das Emas (Goiás state); 3) Manso River (Mato Grosso state); 4) Pampa from Santa Maria (Rio Grande do Sul state); 5) Pantanal from Poconé (Mato Grosso state); 6) Caatinga from Exu (Pernambuco state); 7) Estação Ecológica Juréia-Itatins (São Paulo state); 8) southern Bahia (Bahia state); 9) Central Amazon (Manaus; Amazonas state); and 10) East Amazon (Pará state).

Figura 1. Localidades de Cerrado ( $\square$ ), outras áreas abertas (Pantanal, Pampa e Caatinga; $\Delta$ ), Mata Atlântica (O) e Amazônia (Ъ) utilizadas para comparação de taxocenoses de serpentes brasileiras: 1) Itirapina (SP); 2) Parque Nacional das Emas (GO); 3) Rio Manso (MT); 4) Pampa de Santa Maria (RS); 5) Pantanal de Poconé (MT); 6) Caatinga de Exu (PE); 7) Estação Ecológica Juréia-Itatins (SP); 8) sul da Bahia (BA); 9) Amazônia Central (Manaus; AM); e 10) Amazônia Oriental (PA).

6) Local collectors (see Cunha \& Nascimento 1978). We distributed $30 \mathrm{~L}$ plastic containers with $10 \mathrm{~L}$ of $10 \%$ formaldehyde to people from farms and properties surrounding the reserve, in which they stored snakes they killed during their daily activities. We did not ask local inhabitants to kill the snakes. We just asked them to save the snakes they normally kill. We distributed eight containers, which were inspected monthly, so the total sampling effort was 167 container-months. The eight localities where we distributed the containers included different Cerrado physiognomic forms, but all had human disturbances. Therefore, the snakes collected by this method were considered as coming from disturbed areas.

Specimens collected were deposited in the Museu de História Natural da Universidade Estadual de Campinas (ZUEC), and Coleção Herpetológica Alphonse Richard Hoge of the Instituto Butantan (IBSP). However, most of the individuals captured were marked and released at the site of capture.

We considered rarely, with intermediate frequency and frequently found the species with one to eight records, 12 to 21 , and more than 30 records, respectively (see Table 1 ).

\section{Laboratory work}

Besides the snakes found during our study, we included in our species list (Table 1) records of six specimens from literature and scientific collections belonging to two species: Phalotris multipunctatus 
Table 1. Snakes recorded in the Estação Ecológica de Itirapina and the Itirapina region. Number of individuals found (N) and percentage of the total number of individuals $(\%)$.

Tabela 1. Serpentes registradas na Estação Ecológica de Itirapina e região de Itirapina. Número de indivíduos (N) e porcentagem em relação ao número total de indivíduos (\%).

\begin{tabular}{|c|c|c|}
\hline Family/Species & $\mathbf{N}$ & $\%$ \\
\hline \multicolumn{3}{|l|}{ LEPTOTYPHLOPIDAE } \\
\hline Leptotyphlops koppesi Amaral, 1955 & 20 & 2,6 \\
\hline \multicolumn{3}{|l|}{ BOIDAE } \\
\hline Boa constrictor Stull, 1932 & 12 & 1,6 \\
\hline Epicrates cenchria (Cope 1862) ${ }^{1}$ & 1 & 0,1 \\
\hline Apostolepis dimidiata (Jan 1862) & 8 & 1,1 \\
\hline Atractus pantostictus Fernandes \& Puorto 1993 & 37 & 4,9 \\
\hline Boiruna maculata (Boulenger 1896) ${ }^{2}$ & 1 & 0,1 \\
\hline Chironius flavolineatus (Boettger 1885) & 14 & 1,9 \\
\hline Helicops modestus Günther, 1861 & 8 & 1,1 \\
\hline Liophis meridionalis (Schenkel 1902) & 36 & 4,8 \\
\hline Liophis poecilogyrus (Schlegel 1837) & 32 & 4,2 \\
\hline Lystrophis nattereri (Steindachner 1869) & 21 & 2,8 \\
\hline Oxyrhopus guibei (Hoge \& Romano 1977) & 40 & 5,3 \\
\hline Oxyrhopus rhombifer Duméril, Bibron \& Duméril 1854 & 51 & 6,7 \\
\hline Phalotris lativittatus Ferrarezzi 1993 & 7 & 0,9 \\
\hline Phalotris mertensi Hoge, $1955^{1}$ & 6 & 0,8 \\
\hline Phalotris multipunctatus Puorto \& Ferrarezzi, $1993^{2}$ & - & - \\
\hline Philodryas aestiva (Duméril, Bibron \& Duméril 1854) & 3 & 0,4 \\
\hline Philodryas livida (Amaral 1923)² & - & - \\
\hline Philodryas olfersii (Lichtenstein 1823) ${ }^{1,3}$ & - & - \\
\hline Philodryas patagoniensis (Girard 1858) & 6 & 0,8 \\
\hline Pseudablabes agassizii (Jan 1863) & 18 & 2,4 \\
\hline Rhachidelus brazili Boulenger $1908^{1}$ & 1 & 0,1 \\
\hline Sibynomorphus mikani (Schlegel 1837) & 20 & 2,6 \\
\hline Simophis rhinostoma (Schlegel 1837) & 17 & 2,2 \\
\hline Taeniophallus occipitalis (Jan 1863) & 12 & 1,6 \\
\hline Tantilla melanocephala (Linnaeus 1758) & 52 & 6,9 \\
\hline Thamnodynastes hypoconia (Cope 1860) & 32 & 4,2 \\
\hline Waglerophis merremii (Wagler 1824) & 1 & 0,1 \\
\hline \multicolumn{3}{|l|}{ ELAPIDAE } \\
\hline Micrurus frontalis (Duméril, Bibron \& Duméril 1854) & 2 & 0,3 \\
\hline \multicolumn{3}{|l|}{ VIPERIDAE } \\
\hline Bothrops alternatus Duméril, Bibron \& Duméril, 1854 & 75 & 9,9 \\
\hline Bothrops itapetiningae (Boulenger 1907) & 50 & 6,6 \\
\hline Bothrops moojeni Hoge, 1966 & 52 & 6,9 \\
\hline Bothrops pauloensis Amaral, 1925 & 14 & 1,9 \\
\hline Crotalus durissus (Laurenti 1768) & 99 & 13,1 \\
\hline
\end{tabular}

${ }^{1}$ species found inside the Estação Ecológica de Itirapina after the regular sampling.

${ }^{2}$ species not found, but recorded for the region (Puorto \& Ferrarezzi 1993, Thomas \& Fernandes 1996).

${ }^{3}$ species found in the Itirapina region after the end of the regular sampling.

${ }^{1}$ espécies encontradas na Estação Ecológica de Itirapina após a coleta regular de dados.

${ }^{2}$ espécies não encontradas, mas registradas na região (Puorto \& Ferrarezzi 1993, Thomas \& Fernandes 1996).

${ }^{3}$ espécie encontrada na região de Itirapina após o término da amostragem. 
(Puorto \& Ferrarezzi 1993) and Philodryas livida (IBSP 7354, IBSP 7425, IBSP 8087, IBSP 45795, IBSP 56215; C. Nogueira, pers. comm.; Thomas \& Fernandes 1996). Three additional species were recorded for the municipality of Itirapina: Chironius exoletus (IBSP 55359), Erythrolamprus aesculapii (IBSP 51588), and Micrurus lemniscatus (IBSP 49754). As they are not typical of the Cerrado physiognomic forms of the Itirapina region they were not included in our species list (Table 1).

Laboratory work was also carried out to obtain information on morphology, diet, and reproduction. We examined specimens collected during this study in Itirapina and additional specimens from the scientific collections IBSP and ZUEC from other cerrado localities. We measured the snout-vent length (SVL) of 838 preserved snakes to the nearest millimeter with a measuring tape. We also used additional data from 2226 preserved snakes provided by other researchers.

In the Species Accounts we provide the average SVL for each species and the number of specimens measured and/or considered.

\section{Data analysis}

We compared the species composition of Itirapina with those from five other open vegetation areas and four forested areas in Brazil. We included snake assemblages from the following localities in our analysis (Figure 1): Cerrado at Itirapina (São Paulo state; this study); Cerrado at Emas (Goiás state; P. H. Valdujo, pers. comm.); Cerrado at Manso River (Mato Grosso state; Strüssmann 2000; C. Strüssmann, pers. comm.); Pampa at Santa Maria (Rio Grande do Sul state; Cechin 1999); Pantanal at Poconé (Mato Grosso state; Strüssmann \& Sazima 1993); Caatinga at Exu (Pernambuco state; Vitt \& Vangilder 1983); Atlantic Forest at Juréia (São Paulo state; Marques 1998); Atlantic Forest at Bahia (Bahia state; Argôlo 1992); Amazonian forest at Manaus (Amazonas state; Martins \& Oliveira 1998); and Amazonian forest at the eastern portion of the state of Pará (Cunha \& Nascimento 1978). We listed the presence and absence of 201 snake species from 10 snake assemblages; we excluded from each of the ten species lists those species considered as typical of other biomes (see complete species list in Sawaya 2004, in which Philodryas livida was included for Itirapina). We performed a principal coordinates analysis (PCO), using the Gower's similarity coefficient, and a cluster analysis, using the Simple Matching Coefficient as a measure of similarity and the Pair Group Average Method (UPGMA) as the clustering method (Manly 1994, Sneath \& Sokal 1973). The PCO can be viewed as a generalized form of PCA (principal component analysis) and is useful in situations where there are more variables (species) than cases (snake assemblages). The multivariate analyses were performed in MVSP 3.1 software (Kovach 1999).

\section{Taxonomic remarks}

We restricted our identifications to the species level, but we included below some taxonomic remarks related to the forms found at Itirapina.

Boa constrictor Linnaeus, 1758 could include two distinct forms, presently referred to Boa constrictor constrictor, distributed in Amazon and northern portions of Atlantic Forest, Cerrado, and Caatinga, and B. c. amarali occurring in mesophitic forests and central and southern portions of the Cerrado (Henderson et al. 1995, Peters et al. 1986). The later form is recorded in Itirapina. Besides the different distribution, Boa constrictor constrictor has darker coloration (see color picture in Martins \& Oliveira 1998) than Boa constrictor amarali (see below Figure 6).

Epicrates cenchria includes seven subspecies (Pizzatto 2006), but Epicrates cenchria cenchria and E. c. hygrophilus are synonyms, as well as E. c. crassus and E. c. polylepis, and Epicrates c. maurus and E. c. barbouri (Passos 2003). Epicrates cenchria crassus, recorded in Itirapina, is the form that occurs in the Brazilian Cerrado (Passos 2003, Pizzatto et al. 2006).

Liophis poecilogyrus is presently divided in four subspecies (cf. Dixon \& Markezich 1992). Those subspecies were considered as full species by Fernandes (2006). Liophis poecilogyrus schotti, the typical form from the Cerrado, was recorded in Itirapina.

The name Tantilla melanocephala is used in the present study as it is the valid specific name used to the forms that occurs in Amazon and the Cerrado. However, it is possible that the name Tantilla pallida Cope, 1887, synonymized to T. melanocephala by Wilson \& Mena (1980), is applicable to the Cerrado forms (Sawaya \& Sazima 2003).

Crotalus durissus may include seven subspecies, but there is no available study clarifying its taxonomic status (Vanzolini et al. 1980). The form recorded in Itirapina could be assigned to $C$. $d$. terrificus Laurenti, 1768.

\section{Results}

\section{Species composition}

We recorded 36 Cerrado snake species in the Itirapina region, among 755 individuals found in the field and six additional specimens recorded in collections, belonging to 25 genera and five families (Table 1).

\section{Comparisons with other brazilian snake assemblages}

The first two axes of the Principal Coordinates Analysis (PCO; Figure 2) together explained $45.7 \%$ of the total data variance (axis 1: eigenvalue $=0.85$ and $30.0 \%$ of variance; axis 2 : eigenvalue $=0.45$ and $15.7 \%$ of variance). The PCO axis 1 ordinated the snake assemblages in two main groups (dashed lines in Figure 2): group 1 (to the far right) contains the Amazon assemblages, and group 2 (middle of the figure) contains the other assemblages including the two from the Atlantic Forest. Those were also the main groups defined in the cluster analysis (Figure 3 ).

The PCO axis 2 ordinated the open habitats and Atlantic Forest assemblages in two groups, with the open habitat assemblages also divided in two groups: one group of Cerrado assemblages, and another group with the other open habitat assemblages (continuous lines in Figure 2). Those two open habitat assemblage groups (Figure 2) were consistent with the smaller groups defined in the cluster analysis (Figure 3).

\section{Natural history: species accounts}

\section{LEPTOTYPHLOPIDAE}

1. Leptotyphlops koppesi Amaral, 1955,

"cobra cega", Figures 4 and 5

A small species (average snout vent length $(\mathrm{SVL})=241.2 \mathrm{~mm}$; range 141 to $340 \mathrm{~mm} ; \mathrm{N}=40$ ), captured with intermediate frequency at the EEI. We found individuals in open cerrado physiognomic forms inside the EEI: campo cerrado $(\mathrm{N}=11)$, and campo sujo $(\mathrm{N}=8)$. Outside the reserve, we collected only one juvenile (Figure 5) moving on a paved road that crosses a pine plantation. Like other leptotyphlopids, it is primarily a fossorial species which occasionally is active on the surface. It was observed active on the surface during the rainy season, being more abundant in the beginning of the rainy season in October $(\mathrm{N}=6)$, and November $(\mathrm{N}=6)$. We found two active individuals: a juvenile moving at sunset (ca. 06:00 PM) and one adult female at the entrance of an ant nest, at night. It feeds mainly on ant larvae 


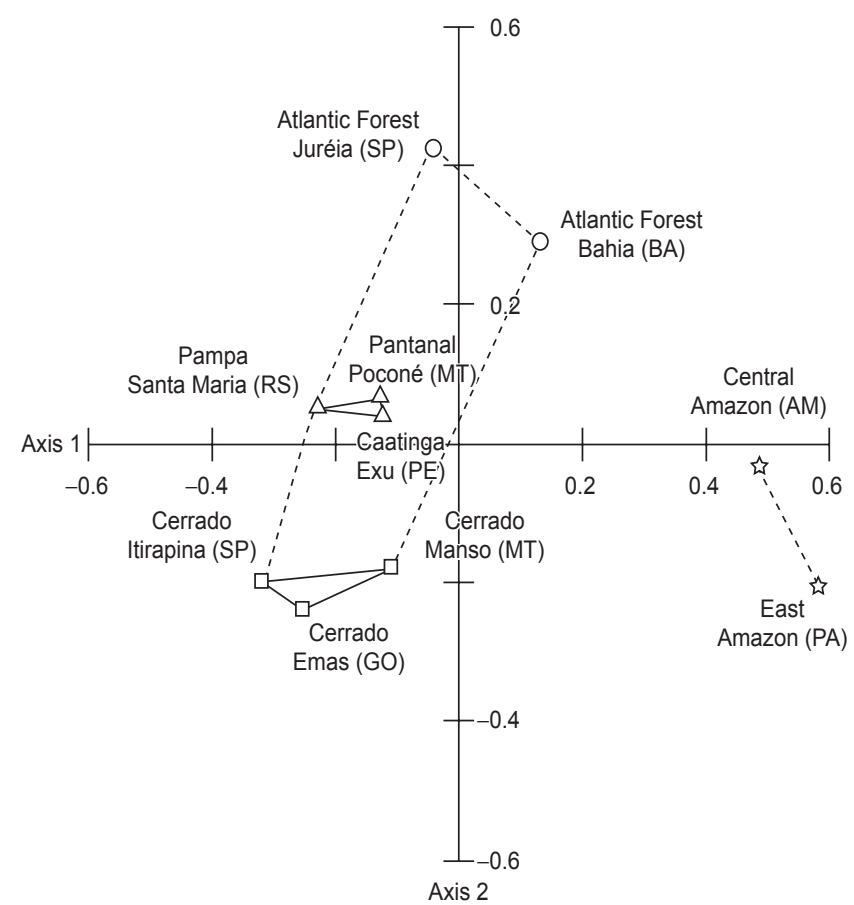

Figure 2. Ordination diagram of Principal Coordinates Analysis (PCO) of snake species composition (presence and absence of 201 species) of six assemblages of open habitats and four assemblages of forested habitats. Axis 1: eigenvalue $=0.86$ and $30.0 \%$ of total variance; Axis 2 : eigenvalue $=$ 0.44 and $15.6 \%$ of total variance. Dashed lines indicate main groups, and continuous lines the smaller groups defined in the cluster analysis dendrogram (see Figure 3). $\square=$ Cerrado assemblages: Cerrado from Emas (GO: Goiás state), Cerrado from Itirapina (SP: São Paulo state), and Cerrado from Manso river (MT: Mato Grosso state); $\Delta=$ other open habitat assemblages: Caatinga from Exu (PE: Pernanbuco state), Pampa from Santa Maria (RS: Rio Grande do Sul state), and Pantanal from Poconé (MT: Mato Grosso state); $\mathrm{O}=$ Atlantic Forest assemblages: Atlantic Forest from Juréia (SP: São Paulo state), and Atlantic Forest from Bahia (BA: Bahia state) = Amazon assemblages: East Amazon (east of Pará, PA: Pará state), and Central Amazon (Manaus, AM: Amazonas state). See species composition of each assemblage in Sawaya (2004).

Figura 2. Diagrama de ordenação da Análise de Coordenadas Principais (PCO) da composição de espécies de serpentes (presença e ausência de $201 \mathrm{spp}$.) de seis taxocenoses de área abertas e quatro de áreas florestais. Eixo 1: autovalor $=0,86$ e $30,0 \%$ de variância; eixo 2: autovalor $=0,44$ e $15,6 \%$ de variância. As linhas pontilhadas indicam os grupos maiores, e as linhas contínuas os grupos menores no dendrograma da análise de agrupamento (veja Figura 3). $\square=$ taxocenoses de Cerrado: Cerrado de Emas (GO), Cerrado de Itirapina (SP), Cerrado do rio Manso (MT); $\Delta=$ taxocenoses de outras áreas abertas: Caatinga de Exu (PE), Pampa de Santa Maria (RS), Pantanal de Poconé (MT); $\mathrm{O}=$ taxocenoses de Mata Atlântica: Mata Atlântica da Juréia (SP) e Mata Atlântica da Bahia (BA); 综 = taxocenoses amazônicas: Amazônia Oriental (leste do Pará, PA) e Amazônia Central (Manaus, AM). Para a composição de espécies de cada taxocenose, veja Sawaya (2004).

and pupae, ingesting adults only occasionally, and less frequently termite soldiers and beetle larvae (R. J. Sawaya, J. P. Miranda, unpublished data). It is an oviparous species, with relatively low fecundity (five to seven eggs), and egg laying probably occurs in the middle of the rainy season, in early December (unpublished data). In the Itirapina region, adults are dark grey on the dorsum, and the venter is light grey (Figure 4), while the juvenile is pink (Figure 5). When handled, it may thrash the body $(\mathrm{N}=1)$ and/ or press the sharp tip of the tail against the captor's hand ( $\mathrm{N}=2$; Figure 4).

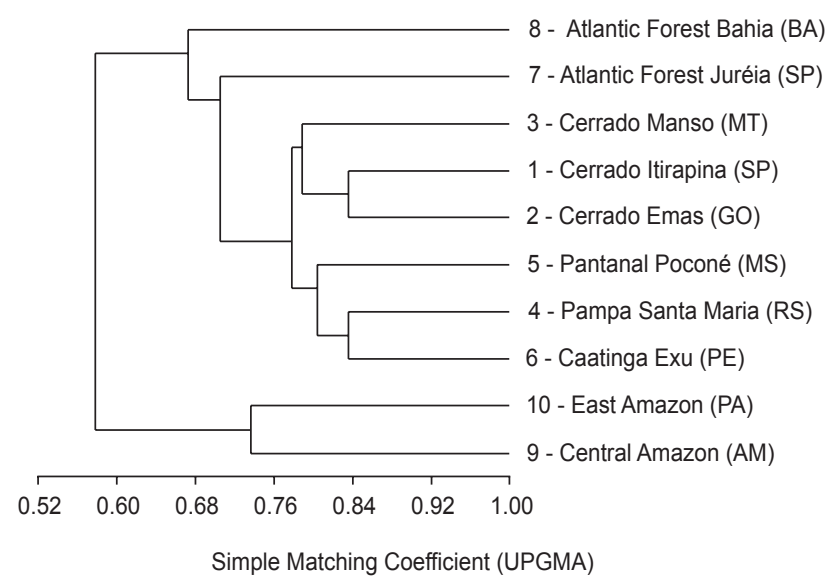

Figure 3. Cluster analysis diagram from snake species composition (presence and absence of 201 species) of six assemblages of open habitats and four assemblages of forested habitats: Central Amazon (Manaus, AM: Amazonas state), East Amazon (east of Pará, PA: Pará state), Caatinga from Exu (PE: Pernanbuco state), Pampa from Santa Maria (RS: Rio Grande do Sul state), Pantanal from Poconé (MT: Mato Grosso state), Cerrado from Emas (GO: Goiás state), Cerrado from Itirapina (SP: São Paulo state), Cerrado from Manso river (MT: Mato Grosso state), Atlantic Forest from Juréia (SP: São Paulo state), and Atlantic Forest from Bahia (BA: Bahia state). See species composition of each assemblage in Sawaya (2004).

Figura 3. Dendrograma da análise de agrupamento resultante da composição de espécies de serpentes (presença e ausência de 201 spp.) de seis taxocenoses de área abertas e quatro de áreas florestais: Amazônia Central (Manaus, AM), Amazônia Oriental (leste do Pará, PA); Caatinga de Exu (PE); Pampa de Santa Maria (RS); Pantanal de Poconé (MT); Cerrado de Emas (GO); Cerrado de Itirapina (SP); Cerrado do Rio Manso (MT); Mata Atlântica da Juréia (SP); e Mata Atlântica da Bahia (BA). Para a composição de espécies de cada taxocenose, veja Sawaya (2004).

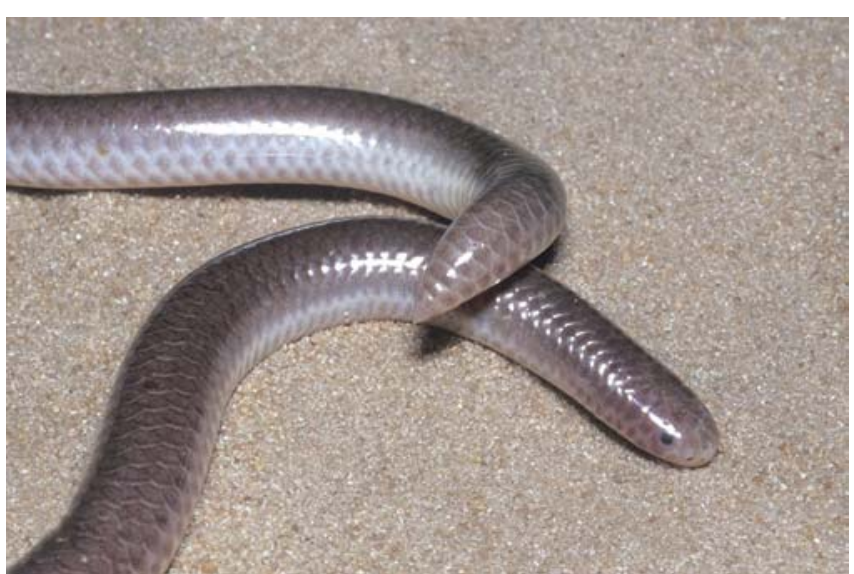

Figure 4. Leptotyphlops koppesi.

Figura 4. Leptotyphlops koppesi.

\section{BOIDAE}

\section{Boa constrictor Linnaeus, 1758, “jibóia”, Figure 6}

A large species (average $\mathrm{SVL}=1024.4 \mathrm{~mm}$; range 390 to $1790 \mathrm{~mm} ; \mathrm{N}=110$ ), rarely found at the EEI, but with intermediate frequency in the Itirapina region. We found this species in almost all vegetation types inside the EEI: campo sujo $(\mathrm{N}=1)$, campo cerrado $(\mathrm{N}=1)$, and border of the gallery forest $(\mathrm{N}=2)$. It was 


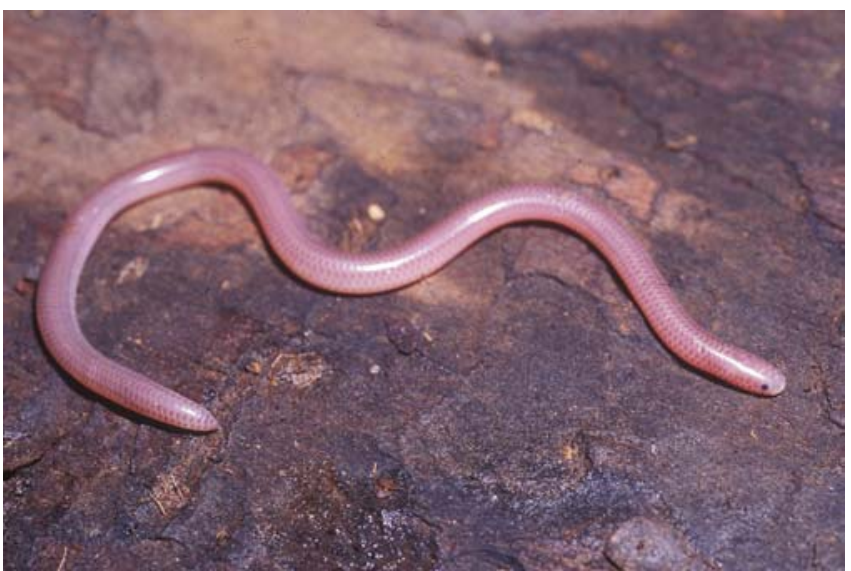

Figure 5. Leptotyphlops koppesi juvenile; photo: O. A. V. Marques.

Figura 5. Leptotyphlops koppesi jovem; foto: O. A. V. Marques.

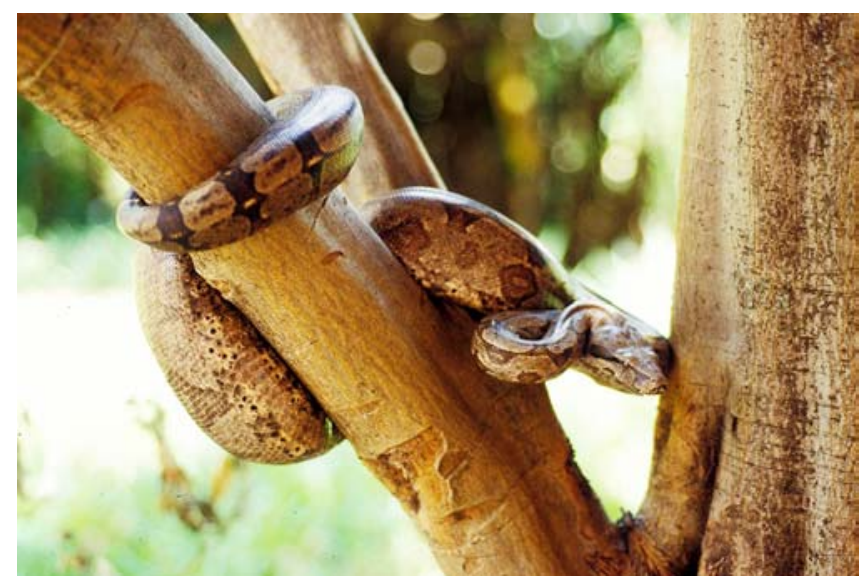

Figure 6. Boa constrictor.

Figura 6. Boa constrictor.

frequently found outside the reserve in disturbed areas $(\mathrm{N}=7)$, and altered forests along water courses. It is a semiarboreal species, and was found on the ground $(\mathrm{N}=5)$, and on the vegetation ( $\mathrm{N}=2)$, one of them captured over $5 \mathrm{~m}$ above the ground. It was more frequently found during the rainy season, between October and March $(\mathrm{N}=8)$, but was also captured in April, May, and August $(\mathrm{N}=4)$. We found active individuals during the day $(\mathrm{N}=4)$, but it can also be active at night (cf. Vanzolini et al. 1980; Marques et al. 2001). We found six birds and one opossum, Didelphis albiventris (Marsupialia, Didelphidae), in the gut of the specimens examined. It is a viviparous species, and three individuals from the São Paulo state showed 16 vitellogenic ovarian follicles (L. Pizzatto, pers. comm.; Pizzatto 2006). When handled, it may strike $(\mathrm{N}=1)$ and bite $(\mathrm{N}=1)$.

\section{Epicrates cenchria (Cope 1862), "salamanta", Figure 7}

A large species (average SVL $=910.4 \mathrm{~mm}$; range 320 to $1371 \mathrm{~mm} ; \mathrm{N}=107$ ), rarely found at the EEI and the Itirapina region. We found only one individual dead on a paved road near the reserve. After the regular snake sampling we found another individual inside the reserve, at night in the campo sujo. It occurs in open Cerrado habitats (C. Nogueira, pers. comm.). It is mainly a terrestrial species (Pizzatto et al. 2006). It is probably active

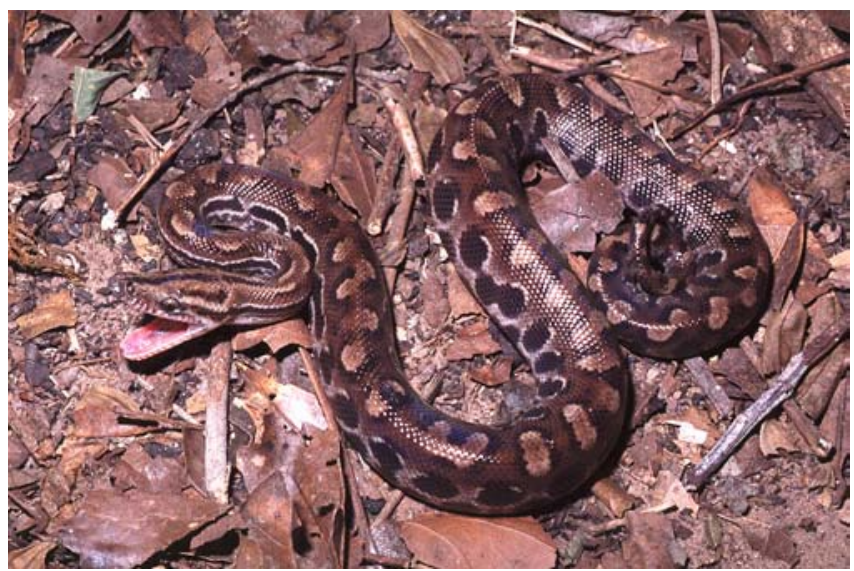

Figure 7. Epicrates cenchria.

Figura 7. Epicrates cenchria.

both during the day and night. Epicrates cenchria feeds mainly on birds and mammals (Henderson 1993). One individual collected in Itirapina and two captured in Mato Grosso state (western Brazil) had fur in its gut contents (L. Pizzatto, pers. comm.). It is a viviparous species. One individual from Mato Grosso do Sul state, Western Brazil, had eight embryos in the oviduct, and another individual from Paraná state, southern Brazil gave birth to 14 newborn (L. Pizzatto, pers. comm.). When disturbed, can gape its mouth ( $\mathrm{N}=1$; Figure 7), bite, coil the tail, and hide the head $(\mathrm{N}=1)$.

\section{COLUBRIDAE}

1. Apostolepis dimidiata (Jan, 1862), "falsa coral", Figures 8 and 9

A small species (average $\mathrm{SVL}=387.8 \mathrm{~mm}$; range 196 to $634 \mathrm{~mm} ; \mathrm{N}=46$ ), rarely found at the EEI and the Itirapina region. We found only three individuals inside the reserve, in open cerrado like campo sujo $(\mathrm{N}=1)$, and campo cerrado $(\mathrm{N}=2)$. We found five individuals in altered areas outside the reserve. Mainly a fossorial species, but also terrestrial, it was found on the soil surface only during the rainy season, between October and March. We found a fresh roadkill at 11:35 PM, indicating nocturnal activity. However, it is possible that it can also be active during the day, as observed for another elapomorfine, Phalotris lativittatus. One preserved specimen had one amphisbaenian in the stomach. Like other elapomorfines, its diet is based probably on amphisbaenians and other elongate fossorial vertebrates (cf. Savitzky 1979). It is an oviparous species, but detailed information on its reproduction is not available. When handled, it may hide the head under the body or burrow it into the soil, and at the same time raise the tail, which is similar in color to the head ( $=1$; Figure 9).

2. Atractus pantostictus Fernandes \& Puorto, 1993, “cobra da terra", Figure 10

A small species (average $\mathrm{SVL}=260.6 \mathrm{~mm}$; range 106 to $469 \mathrm{~mm} ; \mathrm{N}=64$ ), frequently found within EEI. It is limited almost exclusively to riparian areas, especially the border of the gallery forest $(\mathrm{N}=30)$. We also found individuals close to a flooded area $(\mathrm{N}=1)$, in campo cerrado $(\mathrm{N}=1)$, campo sujo $(\mathrm{N}=3)$, and altered areas $(\mathrm{N}=2)$. It is cryptozoic (lives within the leaf litter), but probably also fossorial and terrestrial. Although we caught many individuals with pitfall traps, it is rarely seen. It is active on the surface during the wet season, mainly between October and February, most frequently in October $(\mathrm{N}=12)$. It was found also 


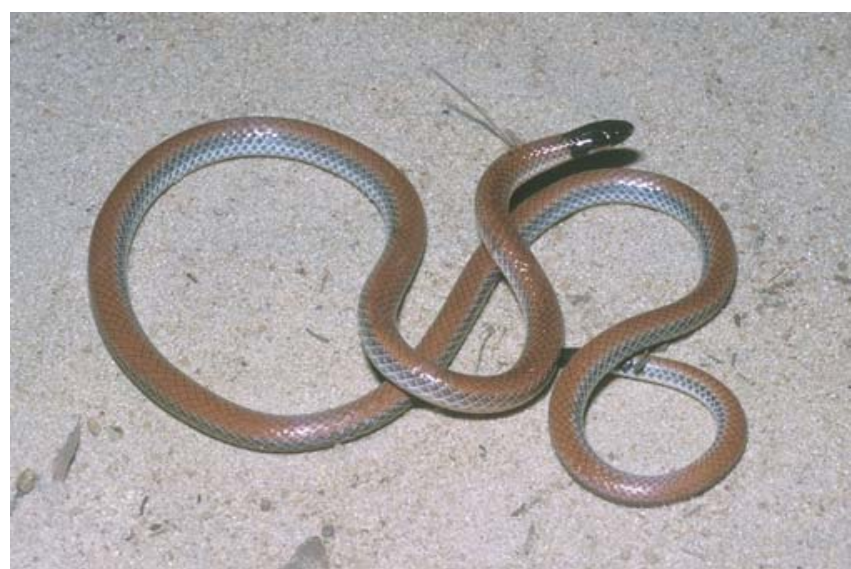

Figure 8. Apostolepis dimidiata.

Figura 8. Apostolepis dimidiata.

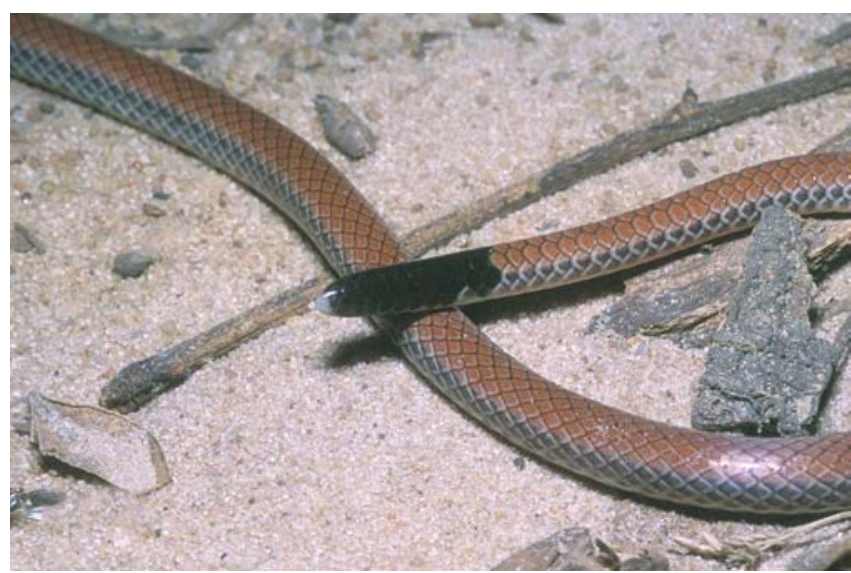

Figure 9. Apostolepis dimidiata.

Figura 9. Apostolepis dimidiata.

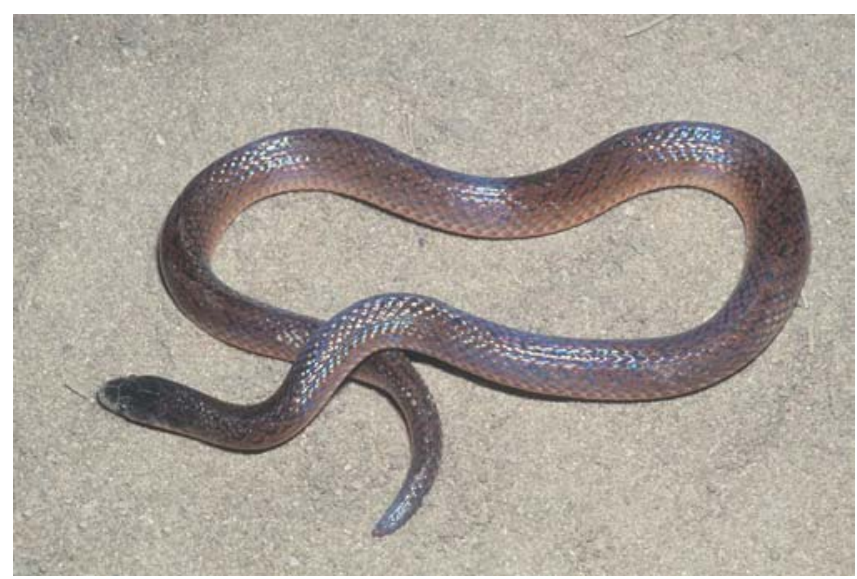

Figure 10. Atractus pantostictus.

Figura 10. Atractus pantostictus.

in September $(\mathrm{N}=3)$ and March $(\mathrm{N}=1)$. Based on four active individuals captured, it is a nocturnal species. The diet is based on earthworms (Oligochaeta; $\mathrm{N}=10$ ), but we found scales of a small lizard in the gut contents of one specimen (R. J. Sawaya, M. E. Oliveira, unpublished data). It is an oviparous species, producing three to four relatively large eggs (Fernandes \& Puorto 1993, Cassimiro et al. 2002). In São Paulo (São Paulo state) one egg clutch was recorded in January (Fernandes \& Puorto 1993), and in Belo Horizonte (Minas Gerais state) one egg clutch was recorded in the beginning of March (Cassimiro et al. 2002), both from captive individuals. Like other Atractus species, A. pantostictus produces relatively large eggs when compared to other colubrids (O. A. V. Marques, pers. obs.).

3. Boiruna maculata (Boulenger 1896), "muçurana", Figure 11

A large species (average $\mathrm{SVL}=809.9 \mathrm{~mm}$; range 306 to $1467 \mathrm{~mm} ; \mathrm{N}=106$ ), rarely found in the Itirapina region. We did not find specimens during the sampling period. The species was recorded in a private snake collection of a local inhabitant. No individual was found inside the reserve but it is likely this terrestrial species occurs there. As observed for related species, it is typical of open Cerrado habitats (C. Nogueira, com. pess.). The diel activity is unknown, but it is probably nocturnal like other pseudoboines (Marques 1998). Like other species related to the genus Clelia, it probably feeds on lizards, snakes, and mammals (Vanzolini et al. 1980, Marques et al. 2001, Pinto $\&$ Lema 2002). One preserved specimen had a snake in the stomach (L. Pizzatto, pers. comm.). It is an oviparous species that lays four to 15 eggs and breeds throughout the year (Pizzatto 2005).

4. Chironius flavolineatus (Boettger 1885), "cobra cipó”, Figure 12

A moderate-size species (average $\mathrm{SVL}=620.1 \mathrm{~mm}$; range 245 to $842 \mathrm{~mm} ; \mathrm{N}=46$ ), found with intermediate frequency at EEI and in the Itirapina region. We found this species in all cerrado physiognomic forms, like marsh $(\mathrm{N}=1)$, border of gallery forest $(\mathrm{N}=3)$, campo sujo $(\mathrm{N}=3)$, and campo cerrado $(\mathrm{N}=3)$. It occurs also in altered areas outside the reserve $(\mathrm{N}=4)$. It is a semiarboreal species (Dixon et al. 1993), but is often found on the ground, as we captured most of the individuals in pitfall traps $(\mathrm{N}=7)$ or killed on roads $(\mathrm{N}=3)$. The only specimen observed on the vegetation was resting on a small tree in a campo sujo area, ca. $2 \mathrm{~m}$ high, around 11:00 PM. It was captured more frequently during the rainy season, between October and March $(\mathrm{N}=10)$, but it was also found in April $(\mathrm{N}=2)$, July $(\mathrm{N}=4)$, and August $(\mathrm{N}=1)$. A higher activity in October and December was also mentioned by Dixon et al. (1993). We found two of the three individuals killed on roads during the day, and another individual was observed being preyed upon by a white-tailed hawk, Buteo albicaudatus (Accipitridae), around 10:30 AM (Sawaya et al. 2003a). Thus, it is probably a diurnal species, as other species of the genus (cf. Marques et al. 2001, Rodrigues 2007). It feeds mainly on amphibians of the family Hylidae (Dixon et al. 1993). It is an oviparous species. There are records of females with eggs in the oviduct collected in November and December, and the number of eggs varies from three to eight (cf. Dixon et al. 1993).

5. Helicops modestus Günther, 1861, "cobra d'água”, Figure 13

A small species (average $\mathrm{SVL}=328.6 \mathrm{~mm}$; range 116 to $633 \mathrm{~mm} ; \mathrm{N}=228$ ), rarely found at the EEI and the Itirapina region, possibly due to our scant sampling in aquatic habitats. We found four individuals in a natural pond near a stream lined by a gallery forest. After the sampling period, some individuals were also found in temporary ponds inside tadpole traps (C. A. Brasileiro, pers. comm.) and in pitfall traps on the border of a gallery forest. It occurs also in altered areas around the reserve $(N=4)$. It is an aquatic species, rarely found far from 


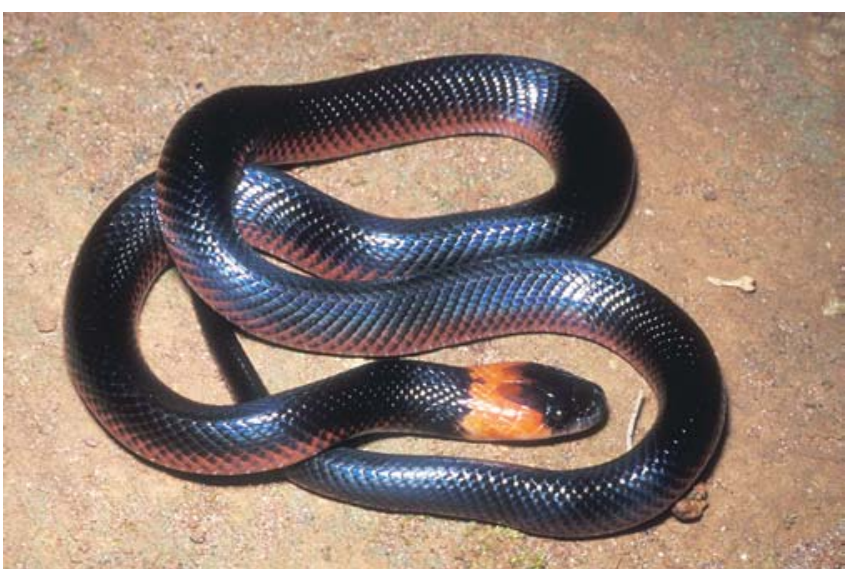

Figure 11. Boiruna maculata (juvenile; Botucatu, SP; photo: I. Sazima).

Figura 11. Boiruna maculata (jovem; Botucatu, SP; foto: I. Sazima).

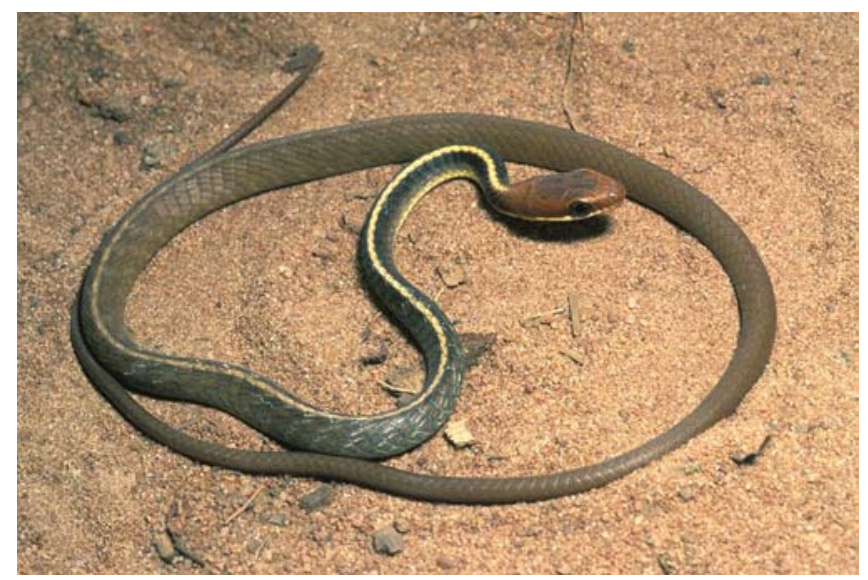

Figure 12. Chironius flavolineatus.

Figura 12. Chironius flavolineatus.

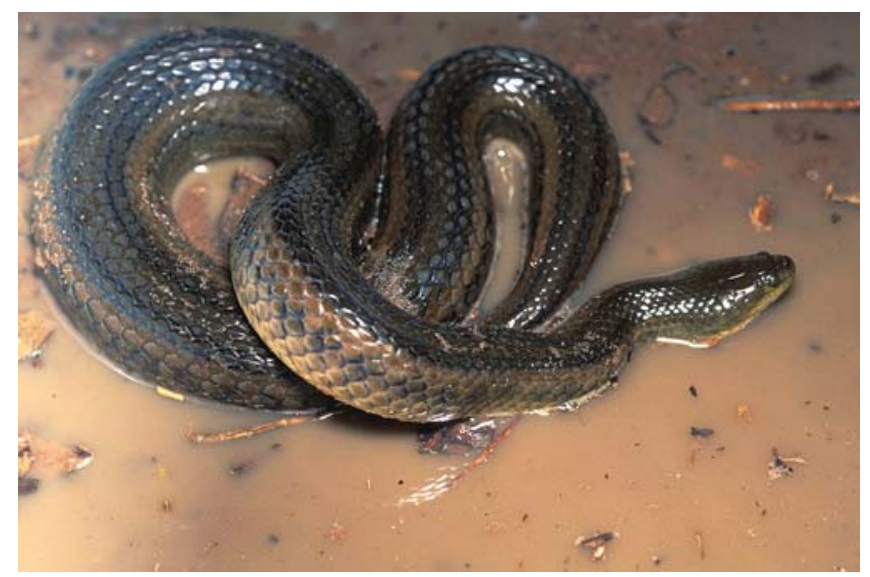

Figure 13. Helicops modestus (Jundiaí, SP).

Figura 13. Helicops modestus (Jundiaí, SP).

water bodies. We found individuals in October and April $(\mathrm{N}=$ 8 ), six of them at night. It feeds on fish and anurans (adults and tadpoles). It is a viviparous species, and in southeastern Brazil its reproductive cycle is seasonal, with vitelogenic follicles and embryos present from September to March (Albolea 1998, Lopes
\& Abe 1981, Picchi 2001), and it gives birth to 2-45 neonates (Lopes \& Abe 1981).

6. Liophis jaegeri (Günther, 1858), “cobra verde”, Figure 14

A small species (average $\mathrm{SVL}=339.2 \mathrm{~mm}$; range 196 to $477 \mathrm{~mm} ; \mathrm{N}=49$ ), rarely found at the EEI. We found two individuals at the border of the gallery forest and one in campo sujo. It was not found outside the reserve. It is probably a terrestrial species, as most of the species of the genus, but it can also be semi-fossorial or semi-aquatic (cf. Dixon 1980). We found active individuals at the EEI in September $(\mathrm{N}=1)$, January $(\mathrm{N}=1)$, and March ( $\mathrm{N}=1)$. In Rio Grande do Sul state it is active between October and April (Di-Bernardo 1998). It is mainly a diurnal species, but it can be active at night (Cechin 1999, Di-Bernardo 1998). It is specialized in anurans (Cechin 1999, Di-Bernardo 1998), mainly leptodactylids (Frota 2005). It is an oviparous species, and the reproductive cycle is seasonal, with vitellogenic ovarian follicles from August to March, and eggs in the oviduct from September to January (Frota 2005).

7. Liophis meridionalis (Schenkel 1902), "cobra listrada", Figures 15 and 16

A small species (average $\mathrm{SVL}=414 \mathrm{~mm}$; range 141 to $649 \mathrm{~mm}$; $\mathrm{N}=100$ ), frequently found at the EEI. We found individuals mainly in campo sujo $(\mathrm{N}=21)$, but also in campo cerrado $(\mathrm{N}=6)$, and at the border of the gallery forest $(\mathrm{N}=8)$. Only one specimen was found in an altered area outside the reserve. It seems to be more active during the rainy season, from October to March $(\mathrm{N}=25)$, being captured most often in March $(\mathrm{N}=10)$. We also found active individuals in April $(\mathrm{N}=3)$, June $(\mathrm{N}=2)$, July $(\mathrm{N}=1)$, August $(\mathrm{N}=3)$, and September $(\mathrm{N}=2)$. We recorded only diurnal activity $(\mathrm{N}=2)$. Its diet is specialized on anurans $(\mathrm{N}=5)$. It is an oviparous species, and the female reproductive cycle is seasonal, with vitelogenesis from September to March (J. E. S. Natali, R. J. Sawaya, unpublished data). One preserved female (SVL $505 \mathrm{~mm}$ ) from São Paulo State had seven eggs in the oviduct. When handled, it may discharge from the cloaca $(\mathrm{N}=1)$, thrash the body $(\mathrm{N}=6)$, and/or gape the mouth exhibiting the red and black tongue $(\mathrm{N}=4$; Figure 16).

8. Liophis poecilogyrus (Schlegel, 1837), "cobra capim", Figures 17, 18 and 19

A moderate-sized species (average $\mathrm{SVL}=379.9 \mathrm{~mm}$; range 118 to $807 \mathrm{~mm} ; \mathrm{N}=200$ ), frequently found at the EEI. We found individuals mainly at the border of the gallery forest $(\mathrm{N}=15)$ and in campo sujo $(\mathrm{N}=10)$, but also in campo cerrado $(\mathrm{N}=2)$ and marshes $(\mathrm{N}=1)$. Only three individuals were found in altered areas outside the reserve. It is a terrestrial species (Vitt 1983, Strüssmann \& Sazima 1993, Marques et al. 2001). It is more active during the rainy season, between October and March $(\mathrm{N}=27)$, being more common in October $(\mathrm{N}=7)$ and November $(\mathrm{N}=7)$. It was also found active in April $(\mathrm{N}=2)$ and September $(\mathrm{N}=3)$. We recorded only nocturnal activity $(\mathrm{N}=2)$ in the field, and two individuals were found resting during the day under coverboards. It is probably also diurnal, since diurnal activity was recorded in other regions (Dixon \& Markezich 1992, Strüssmann \& Sazima 1993, Marques et al. 2001). It is specialized on frogs ( $\mathrm{N}=8$; cf. Strüssmann \& Sazima 1993), although lizards were also recorded as prey $(\mathrm{N}=2)$. It is an oviparous species that produces four to nine eggs $(\mathrm{N}=5)$. Secondary vitelogenesis occurs from August to February (L. Okayama, R. J. Sawaya, unpublished data). 


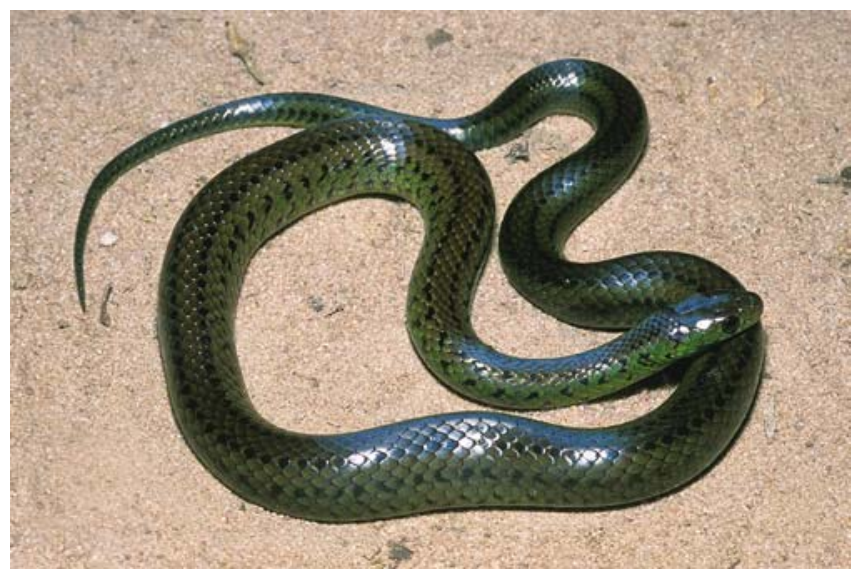

Figure 14. Liophis jaegeri.

Figura 14. Liophis jaegeri.

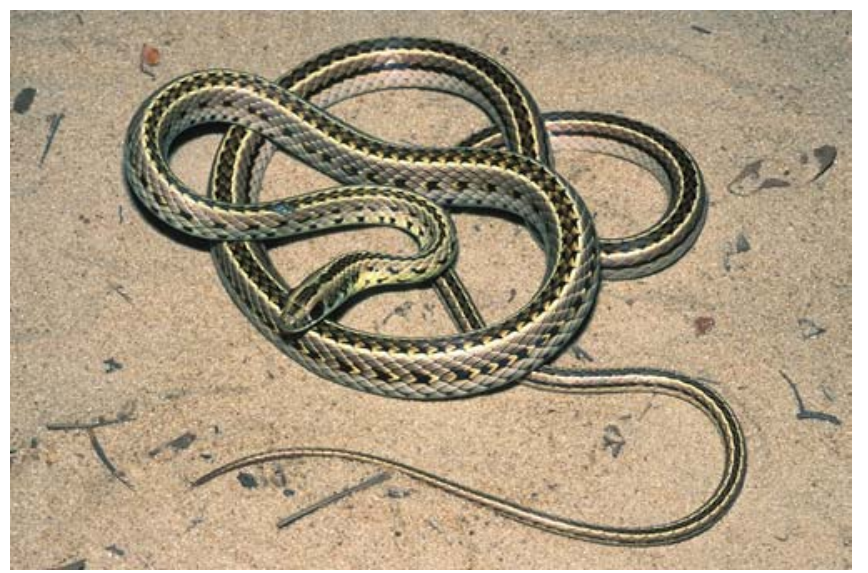

Figure 15. Liophis meridionalis.

Figura 15. Liophis meridionalis.

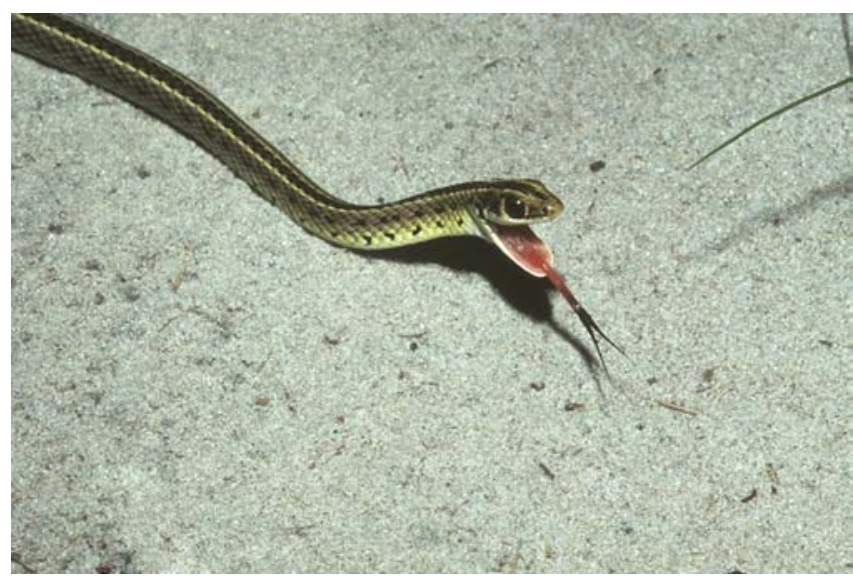

Figure 16. Liophis meridionalis.

Figura 16. Liophis meridionalis.

Egg laying probably occurs around the beginning of the rainy season, as we recorded females with eggs in October $(\mathrm{N}=2)$, November $(\mathrm{N}=1)$, and December $(\mathrm{N}=1)$. Hatching probably occurs at the end of the rainy season from January to April. In

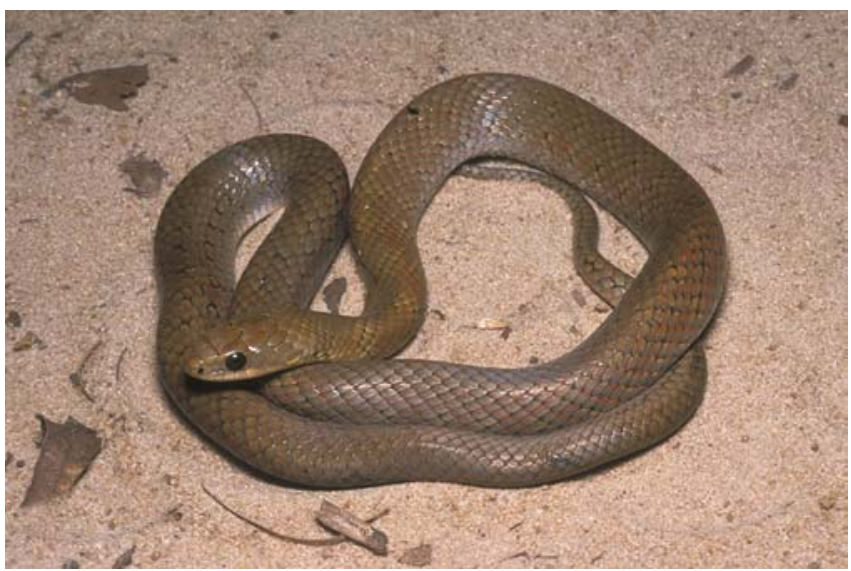

Figure 17. Liophis poecilogyrus.

Figura 17. Liophis poecilogyrus.

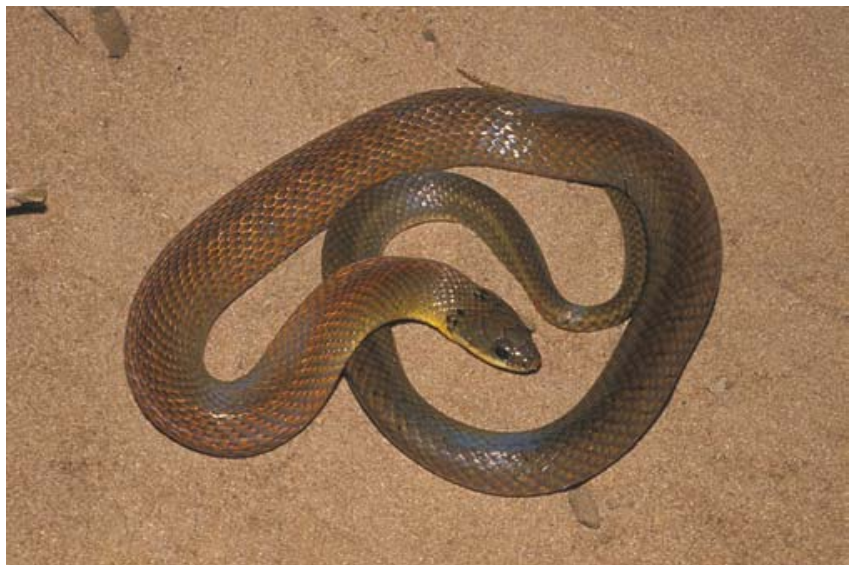

Figure 18. Liophis poecilogyrus.

Figura 18. Liophis poecilogyrus.

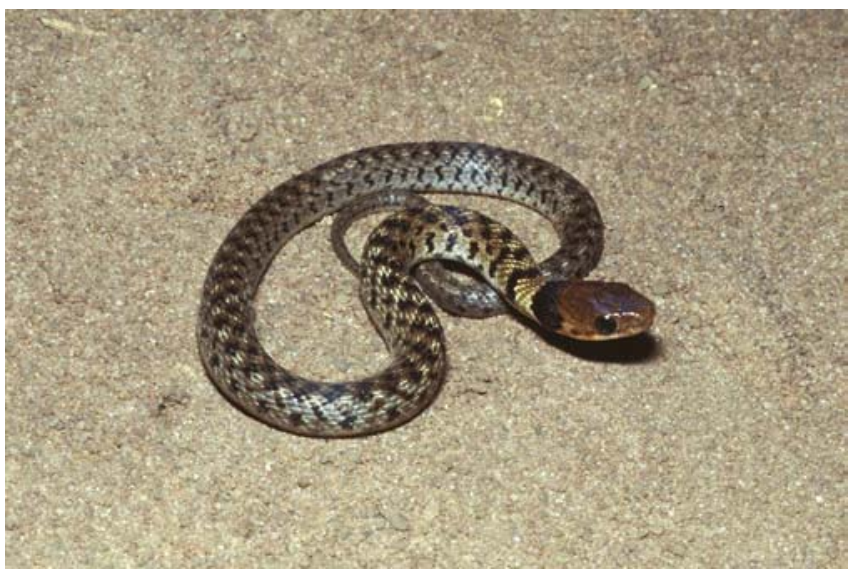

Figure 19. Liophis poecilogyrus (juvenile).

Figura 19. Liophis poecilogyrus (jovem).

southern Brazil its reproductive cycle is highly seasonal (Maciel 2001), but it is possible that at lower latitudes its reproductive cycle is longer; such latitudinal variation was described for the congeneric L. miliaris (Pizzatto 2003). The population from EEI

http://www.biotaneotropica.org.br/v8n2/en/abstract?inventory+bn01308022008 
shows great variation in color pattern, from brown (Figure 17) to reddish brown (Figure 18), yellowish brown or combinations of those patterns, with or without a black nuchal collar. Juveniles always show a brown and black variegated pattern, a black nuchal collar and a brown head (Figure 19). When handled, it may flatten the body $(\mathrm{N}=3)$, triangulate the head $(\mathrm{N}=3)$, discharge from the cloaca $(\mathrm{N}=3)$ thrash the body $(\mathrm{N}=1)$ and/or gape the mouth $(\mathrm{N}=1)$.

9. Lystrophis nattereri (Steindachner 1869), "cobra-nariguda", Figure 20

A small species (average $\mathrm{SVL}=272.2 \mathrm{~mm}$; range 135 to $442 \mathrm{~mm} ; \mathrm{N}=73$ ), found with intermediate frequency at the EEI. It was virtually restricted to the campo sujo. Of the 21 individuals found, 20 were in campo sujo, and one at the transition between campo sujo and gallery forest. We did not find any individual outside the reserve. It is a habitat specialist species, occurring in areas of sandy soil, and its populations seem to be declining in São Paulo state (Marques et al. 1998, Sawaya 2004). In Brasília and Parque Nacional das Emas (central Brazil), where the species seems relatively rare, it is also restricted to open Cerrado areas and some specimens were found in clay rich soils (C. Nogueira, pers. comm.). As other open cerrado and grassland species, it is probably highly threatened in São Paulo state.

It is possibly a fossorial and terrestrial species, as Lystrophis dorbignyi, a common species in sand dunes of Rio Grande do Sul state (Oliveira et al. 2001). Its activity on the surface is virtually limited to the rainy season, being more captured in October $(\mathrm{N}=5)$ and November $(\mathrm{N}=5)$. We found only one individual in April and another one in August. It is probably a diurnal species since we found two individuals active during the day, at 06:25 AM and 04:15 PM. Other three specimens observed in other Cerrado areas were also active during the day (C. Nogueira, pers. comm.). The specimen found at 06:25 AM was being preyed upon by a whitetailed hawk, Buteo albicaudatus (Accipitridae; Brasileiro et al. 2003). It feeds mainly on lizard and/or snake eggs $(\mathrm{N}=6)$ and gymnophthalmid lizards ( $\mathrm{N}=3$; R. J. Sawaya, C. A. Brasileiro, unpublished data). It is an oviparous species, and lays two to ten eggs $(\mathrm{N}=6)$, five on average. The specimens examined indicate a seasonal reproductive cycle with secondary vitelogenesis from October to February. Its color pattern in Itirapina (Figure 20) is very similar to that of Bothrops itapetiningae (Figure 41), of which it is possibly a mimic (Brasileiro et al. 2003). When handled, it may flatten the body $(\mathrm{N}=3)$, thrash the body $(\mathrm{N}=2)$, strike with the mouth closed (false strike; $\mathrm{N}=1$ ), and coil the tail $(\mathrm{N}=1)$.

10. Oxyrhopus guibei (Hoge \& Romano 1977), "falsa coral", Figure 21

A moderate-sized species (average $\mathrm{SVL}=615.4 \mathrm{~mm}$; range 189 to $1060 \mathrm{~mm} ; \mathrm{N}=222$ ), frequently found at the EEI and the Itirapina region. We found individuals throughout all cerrado physiognomic forms like border of gallery forest $(\mathrm{N}=12)$, campo sujo $(\mathrm{N}=8)$, campo cerrado $(\mathrm{N}=6)$, and altered areas inside and outside the reserve $(\mathrm{N}=11)$. It is mainly terrestrial, but we found one adult moving on a grass tuft about $30 \mathrm{~cm}$ from the ground. It is active throughout the year, but found more frequently in October $(\mathrm{N}=9)$ and March $(\mathrm{N}=6)$. In southeastern Brazil the adults seem to be less active at the end of the rainy season, and more active at the beginning of the rainy season (Pizzatto \& Marques 2002). We found this species active mainly at night $(\mathrm{N}=5)$, but one individual was found active during the day. It feeds mainly on lizards and mammals (Sazima \& Abe 1991, Sazima \& Haddad 1992, Andrade \& Silvano 1996). It is an oviparous species and lays three to 20 eggs. The reproductive cycle is continuous, but the recruitment occurs mainly at the end of the rainy season and the beginning of the dry season (Pizzatto $\&$ Marques 2002). Its color pattern (triads) is similar to that of the coral snake Micrurus frontalis (see Figure 21 and 39), which also occurs at the EEI. Thus, it may be considered a mimic of M. frontalis. When handled, it may thrash the body $(\mathrm{N}=4)$ and discharge from the cloaca $(\mathrm{N}=4)$.

11. Oxyrhopus rhombifer Duméril Bibron \& Duméril, 1854, "falsa coral", Figure 22

A small species (average $\mathrm{SVL}=369 \mathrm{~mm}$; range 149 to $685 \mathrm{~mm}$; $\mathrm{N}=45$ ), frequently found at the EEI. We found individuals mainly in open cerrado physiognomic forms like campo sujo $(\mathrm{N}=24)$ and campo cerrado $(\mathrm{N}=18)$, but it also occurs at the border of the gallery forest $(\mathrm{N}=9)$. We did not find any specimens outside the reserve. It is mainly a terrestrial species, but two juveniles were observed moving on leaves of saplings ca. 15 to $20 \mathrm{~cm}$ from the ground. It is active virtually throughout the year, but it was found most frequently in March ( $\mathrm{N}=15)$. It is mainly a nocturnal species $(\mathrm{N}=6)$, but we found one individual active during the

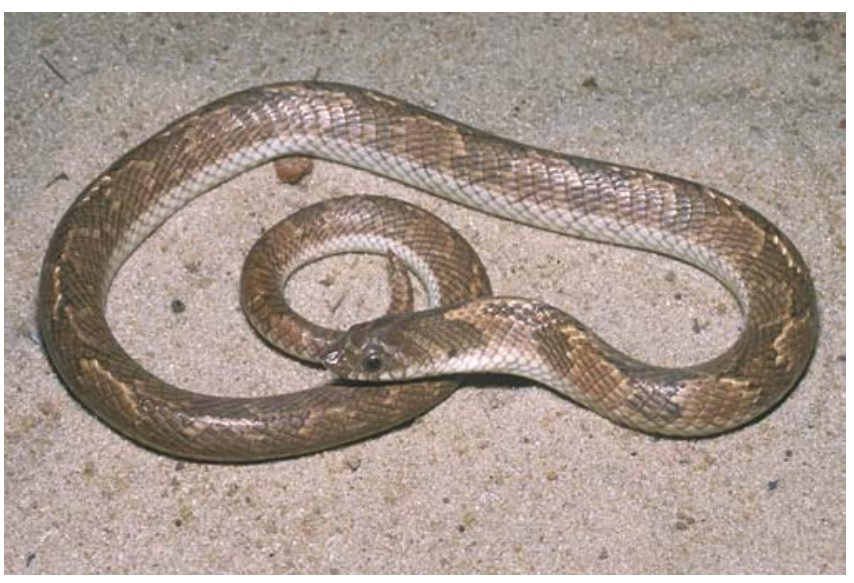

Figure 20. Lystrophis nattereri.

Figura 20. Lystrophis nattereri.

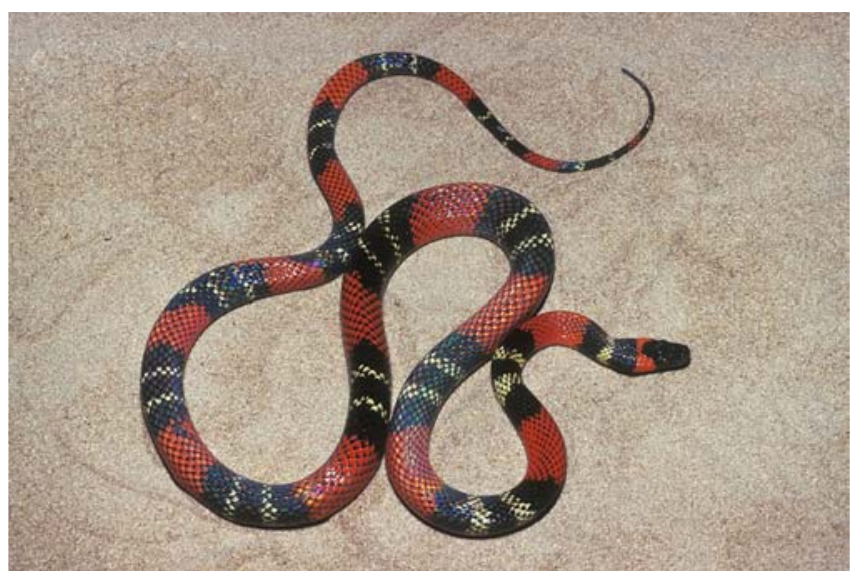

Figure 21. Oxyrhopus guibei.

Figura 21. Oxyrhopus guibei. 


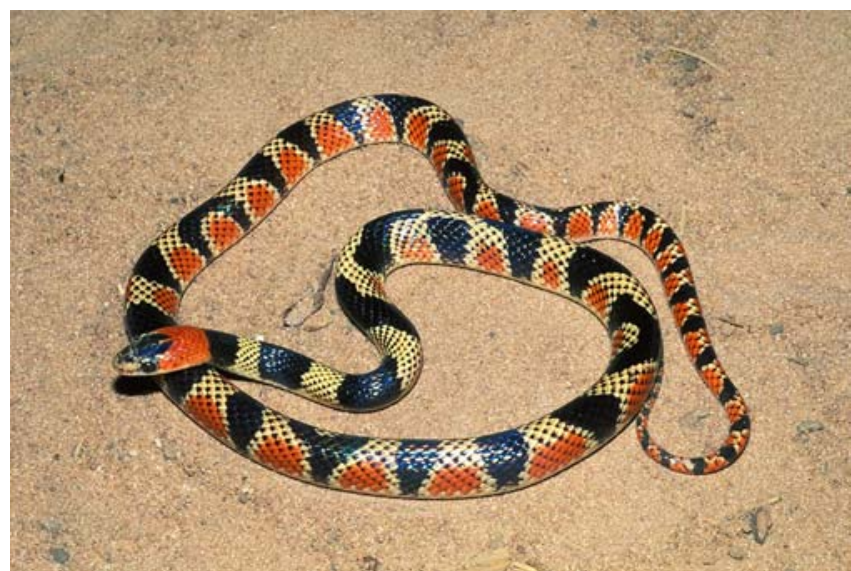

Figure 22. Oxyrhopus rhombifer.

Figura 22. Oxyrhopus rhombifer.

day $(\mathrm{N}=1)$. One individual was observed being preyed upon by a Burrowing Owl, Speotyto cunicularia (Strigidae), at 9:45 PM (Sawaya et al. 2003b). It feeds on lizards $(\mathrm{N}=5)$ and mammals ( $\mathrm{N}=7$; R. J. Sawaya, L. Pizzatto, unpublished data). It is an oviparous species, but detailed information on its reproduction is not available. Its color pattern consists of red, yellow, and black irregular bands. It may be considered an imperfect mimic of coral snakes (see Figures. 22 and 39). When handled, it may discharge from the cloaca $(\mathrm{N}=8)$, thrash the body $(\mathrm{N}=7)$, and flatten the body $(\mathrm{N}=3)$.

\section{Phalotris lativittatus Ferrarezzi, 1993, Figure 23}

A moderate-sized species (average SVL $=487.4 \mathrm{~mm}$; range 232 to $706 \mathrm{~mm} ; \mathrm{N}=40$ ), rarely found at the EEI and the Itirapina region. We found individuals in campo cerrado $(\mathrm{N}=2)$, campo sujo $(\mathrm{N}=1)$, border of the gallery forest $(\mathrm{N}=1)$, and altered areas outside the reserve $(\mathrm{N}=3)$. It is mainly a fossorial species, found active on the surface during the rainy season, from October to February. One individual was found active in the morning, and another at night at 9:05 PM, indicating both diurnal and nocturnal activity. One amphisbaenian was found in its gut (H. Ferrarezzi, pers. comm.). Like other elapomorphines, it is probably specialized on amphisbaenians and other elongate fossorial vertebrates (cf. Savitzky 1979). It is an oviparous species, but detailed information on its reproduction is not available.

\section{Phalotris mertensi Hoge, 1955, "falsa coral", Figure 24}

A large species (average SVL $=802.2 \mathrm{~mm}$; range 304 to $1262 \mathrm{~mm} ; \mathrm{N}=50$ rarely found at the EEI and the Itiapina region. We found six individuals in altered areas outside the reserve. After the regular sampling, one individual was found inside the reserve in campo sujo. It is mainly a fossorial species, found active on the surface during the rainy season from October to March $(\mathrm{N}=6)$. It was observed active during the day $(\mathrm{N}=1)$ and at night $(\mathrm{N}=3)$, indicating it is both diurnal and nocturnal. It is an oviparous species with a seasonal reproductive cycle; vitelogenesis occurs from August to February and eggs in the oviduct were found in December; mating probably occurs around November (C. Herédias-Ribas, R. J. Sawaya, unpublished data). There is no information about its diet, but like other elapomorphines, it is probably specialized

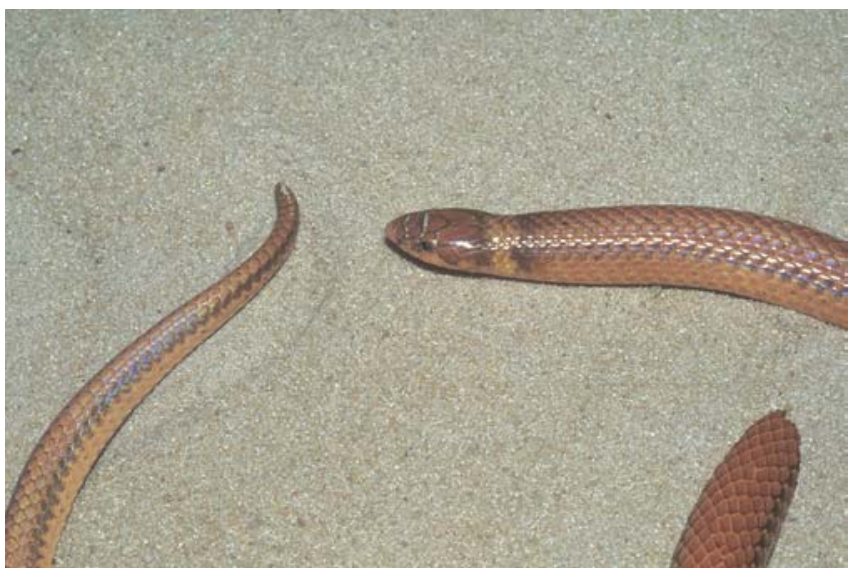

Figure 23. Phalotris lativittatus.

Figura 23. Phalotris lativittatus.

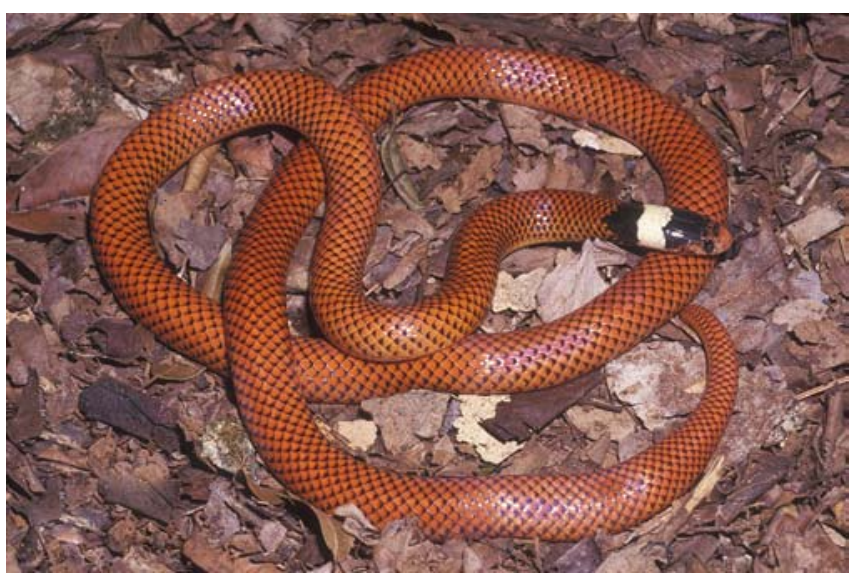

Figure 24. Phalotris mertensi (Paranapanema, SP; photo: O. A. V. Marques).

Figura 24. Phalotris mertensi (Paranapanema, SP; foto: O. A. V. Marques).

on amphisbaenians and other elongate fossorial vertebrates (cf. Savitzky 1979). Its color pattern, with a live red dorsum, a white nuchal band, and a black head (Figure 24), may be considered as mimetic of coral snakes (cf. Savage \& Slowinsky 1992, Sawaya \& Sazima 2003). Indeed, this pattern was less preyed upon (i. e., protected) than controls in experiments with clay models in Costa Rica (Brodie 1993).

14. Phalotris multipunctatus Puorto \& Ferrarezzi, 1993, Figure 25

A small species $(\mathrm{SVL}=239$ to $326 \mathrm{~mm} ; \mathrm{N}=2)$, rarely found at the Itirapina region. Only two specimens are known (holotype and paratype), the former from São Paulo state and the latter from Mato Grosso do Sul state. The specimen from São Paulo state was collected in 24 October 1980 at a farm (Fazenda Elba) in the neighborhood of EEI (Puorto \& Ferrarezzi 1993), thus, it may occur inside the reserve. It may be mainly a fossorial species like its congenerics. There is no information available on its natural history but it probably feeds on elongate fossorial vertebrates, like other congeneric species (cf. Savitzky 1979). 


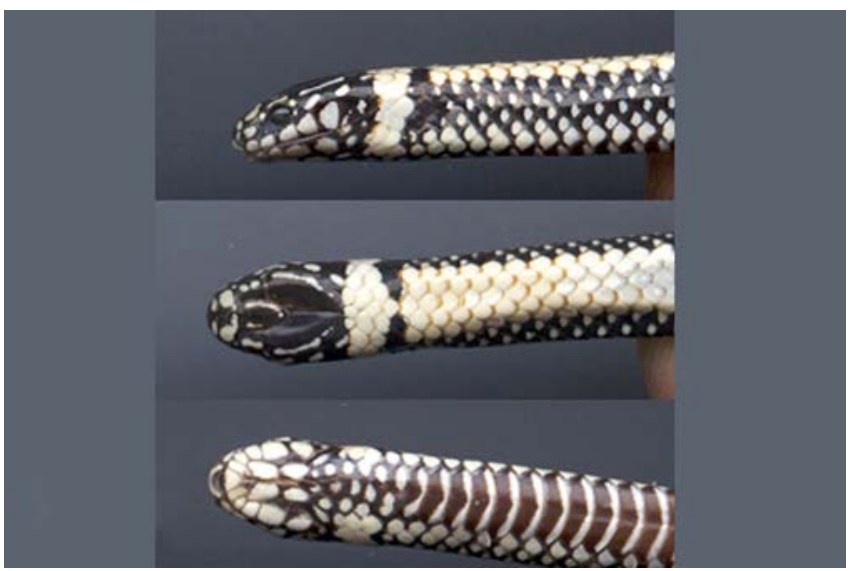

Figure 25. Phalotris multipunctatus (preserved specimen).

Figura 25. Phalotris multipunctatus (espécime fixado).

15. Philodryas aestiva (Duméril Bibron \& Duméril 1854), "cobra verde", Figure 26

A moderate-sized species (average $\mathrm{SVL}=648.6 \mathrm{~mm}$; range 210 to $983 \mathrm{~mm} ; \mathrm{N}=56$ ), rarely found at the EEI. We found three individuals in campo sujo. We did not find any individuals in altered areas outside the reserve. This species is often found on the ground in areas of open cerrado (Serra da Canastra, Minas Gerais state, and Parque Nacional das Emas, Goiás state; M. Martins, pers. obs., P. H. Valdujo, C. Nogueira, pers. comm.). One specimen was found in January and two in February. It is a diurnal species (Di-Bernardo 1998, Marques et al. 2001; M. Martins, pers. obs.). There is no available data on its diet. It is an oviparous species; vitelogenesis occurs from April to December, and ovulation from July to December (Fowler et al. 1998). One captive female laid 11 eggs (Fowler et al. 1998). When handled, it may thrash the body $(\mathrm{N}=2)$, discharge from the cloaca $(\mathrm{N}=1)$, and bite $(\mathrm{N}=1)$.

16. Philodryas livida (Amaral, 1923), "cobra cipó", Figure 27

A moderate-sized species ( $\mathrm{SVL}=471$ to $693 \mathrm{~mm} ; \mathrm{N}=2$ ), rarely found at the Itirapina region. Only five specimens are registered in Itirapina region (Thomas \& Fernandes 1996). One of those specimens was found at a farm (Fazenda Elba) in the neighborhood of EEI, thus it may occur inside the reserve. Its preferred habitat in southern Brazil (Mato Grosso do Sul and São Paulo states) seems to be open Cerrado areas (Thomas \& Fernandes 1996). In central Brazil (Parque Nacional das Emas, Goiás state), it was also found in open Cerrado areas (Valdujo \& Nogueira 1999; C. Nogueira, pers. com.). There is no additional information available on its natural history.

17. Philodryas olfersii (Lichtenstein 1823), "cobra verde", Figure 28

A moderate-sized species (average $\mathrm{SVL}=699.3 \mathrm{~mm}$; range 285 to $1120 \mathrm{~mm} ; \mathrm{N}=129$ ), rarely found at the Itirapina region. We found only one adult specimen (Figure 28) outside the reserve, after the regular sampling. We did not find any individuals inside the reserve, but it probably occurs there. It is a semiarboreal species (Hartmann 2001). It is found in open areas, but mainly in the border and interior of forests, being active mainly in late morning and early afternoon (Sazima \& Haddad1992, Hartmann 2001, Hartmann \& Marques 2005). Philodryas olfersii is an euryphagous species which feeds on anurans, lizards, birds, and mammals (Hartmann 2001, Hartmann \& Marques

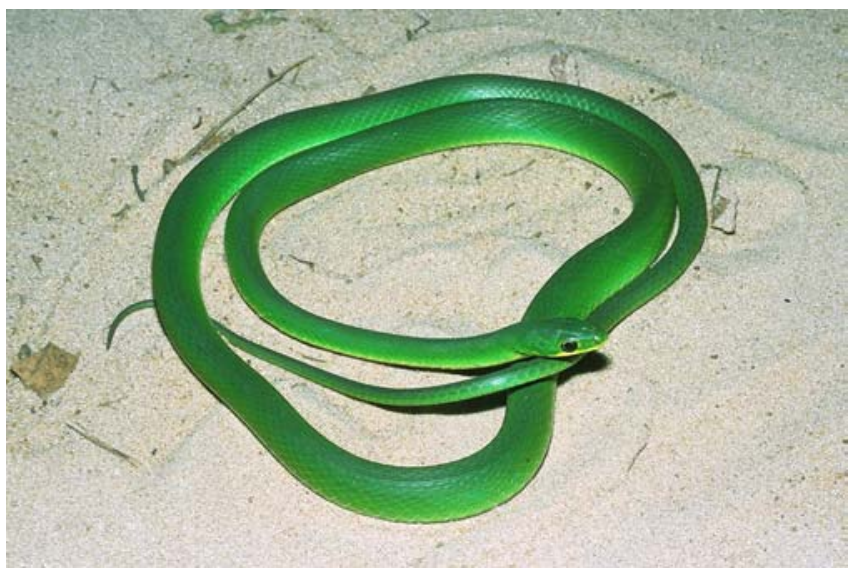

Figure 26. Philodryas aestiva.

Figura 26. Philodryas aestiva

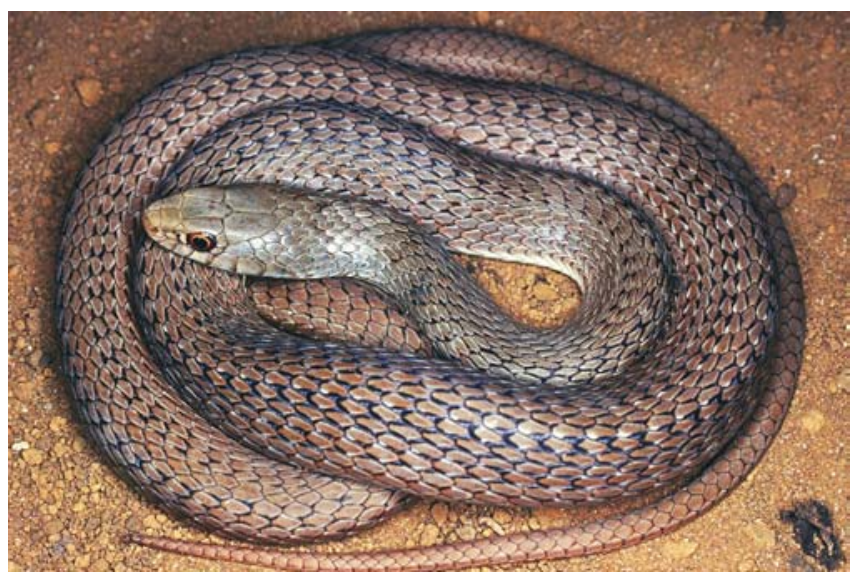

Figure 27. Philodryas livida (Parque Nacional das Emas, GO; photo: C. Nogueira).

Figura 27. Philodryas livida (Parque Nacional das Emas, GO; foto: C. Nogueira).

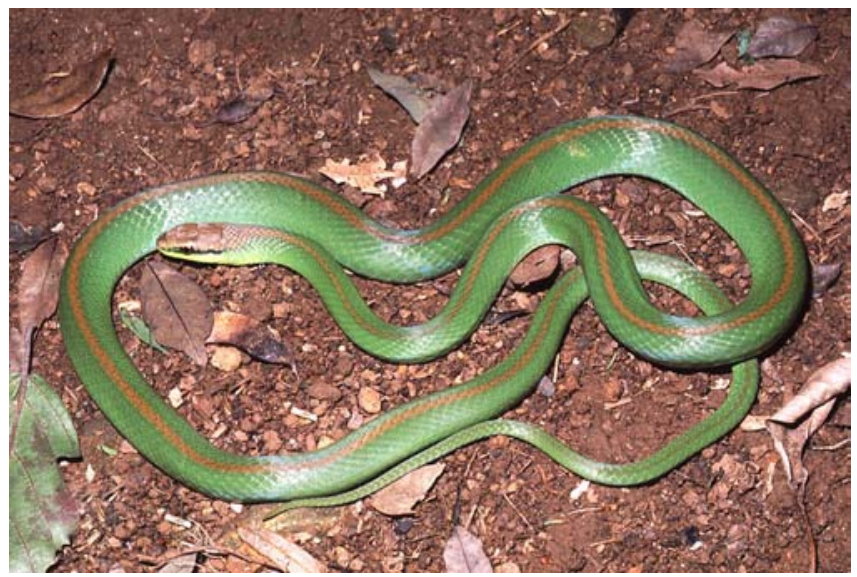

Figure 28. Philodryas olfersii.

Figura 28. Philodryas olfersii.

2005). It is an oviparous species, with secondary vitelogenesis occurring from May to January and ovulation from September to January (Fowler et al. 1998). Information on its fecundity is not available. 
18. Philodryas patagoniensis (Girard 1858), "parelheira”, Figure 29

A moderate-sized species (average $\mathrm{SVL}=696.1 \mathrm{~mm}$; range 205 to $1120 \mathrm{~mm} ; \mathrm{N}=140$ ), rarely found at the EEI and the Itirapina region. We found individuals in campo sujo $(\mathrm{N}=2)$, campo cerrado $(\mathrm{N}=1)$, border of the gallery forest $(\mathrm{N}=1)$, and altered areas outside the reserve $(\mathrm{N}=2)$. It occurs mainly in grasslands (cf. Hartmann 2001, Hartmann \& Marques 2005, C. Nogueira, pers. comm.). It is mainly terrestrial (Fowler \& Salomão 1994, Hartmann 2001, C. Nogueira, pers. comm.), but can use the vegetation occasionaly (Gonzaga et al. 1997, Hartmann 2001, Hartmann \& Marques 2005). It was found active inside the reserve from October to March, which corresponds to the peak of its seasonal activity in other localities. In southern Brazil it was found active from September to June (Di-Bernardo 1998). It was found active during the day ( $=3$; see also Di-Bernardo 1998, Cechin 1999) and it is usually active in the hotter hours of the day (Hartmann 2001). It has a generalized diet, which includes anurans, lizards, snakes, birds, and mammals (Di-Bernardo 1998, Cechin 1999, Hartmann 2001, Hartmann \& Marques 2005). It is an oviparous species that lays three to 19 eggs $(\mathrm{N}=7)$. The reproduction is seasonal, with secondary vitelogenesis occurring from August to December and ovulation from October to December (Fowler et al. 1998). When handled, it may thrash the body $(\mathrm{N}=2)$, discharge from the cloaca $(\mathrm{N}=1)$, and bite $(\mathrm{N}=1)$.

19. Phimophis guerini (Duméril Bibron \& Duméril 1854), Figure 30

A moderate-sized species (average $\mathrm{SVL}=667.2 \mathrm{~mm}$; range 252 to $1038 \mathrm{~mm} ; \mathrm{N}=60$ ), rarely found at the EEI and the Itirapina region. We found individuals only in campo sujo $(\mathrm{N}=3)$ and in an altered area outside the reserve $(\mathrm{N}=1)$. It seems to be a terrestrial species $(\mathrm{N}=3)$. We found active individuals from December to March, at night $(\mathrm{N}=3)$. It feeds mainly on lizards $(\mathrm{N}=10)$, but we also found fur in the gut of a juvenile (R. J. Sawaya, J. P. Miranda, unpublished data). It is an oviparous species, but detailed information on its reproduction is not available. When handled, it may thrash the body $(\mathrm{N}=1)$, discharge from the cloaca $(\mathrm{N}=1)$, and bite $(\mathrm{N}=1)$.

20. Pseudablabes agassizii (Jan 1863), Figure 31

A small species (average $\mathrm{SVL}=306.8 \mathrm{~mm}$; range 200 to 453 $\mathrm{mm} ; \mathrm{N}=100$ ), found with intermediate frequency at the EEI. Almost all individuals were found in campo sujo $(\mathrm{N}=16)$, only

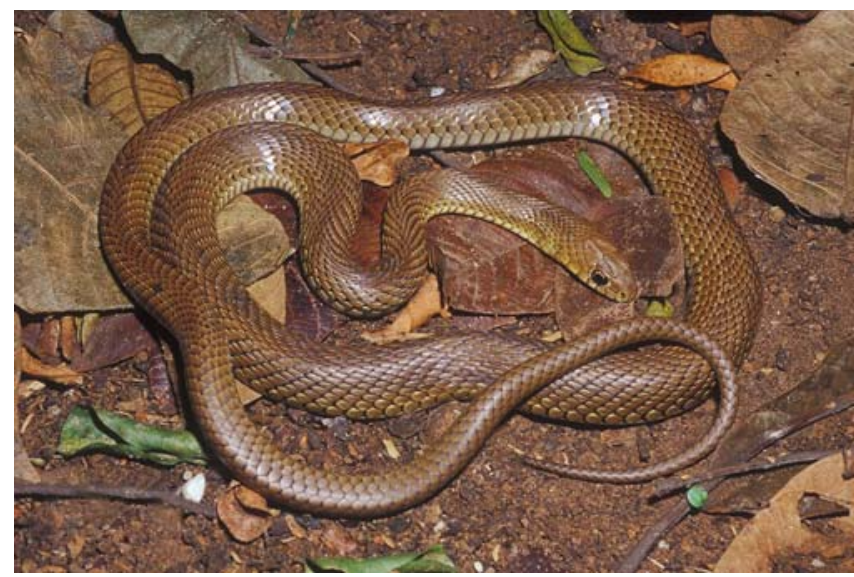

Figure 29. Philodryas patagoniensis (São Paulo state; photo: O. A. V. Marques).

Figura 29. Philodryas patagoniensis (Estado de São Paulo; foto: O.A.V. Marques). one individual was found in campo cerrado and another at the border of the gallery forest. We did not find any individuals in altered areas outside the reserve. It seems to be a habitat specialist in open field habitats (C. Nogueira, pers. comm.) and it is probably threatened in São Paulo state (Marques et al. 2006; Sawaya 2004). It seems to be a primarily terrestrial species (Marques et al. 2006). We found individuals active throughout the year, except in May, June, and July. It is a diurnal species (Marques et al. 2006). It is specialized on spiders, mainly lycosids, but it may also feed on scorpions and lizards (Cei 1993, Marques et al. 2006). It is an oviparous species that produces four to ten eggs, seven on average $(\mathrm{N}=10)$. The reproduction is seasonal with secondary vitelogenesis from June to January, and ovulation from September to February (Marques et al. 2006). Two females collected in the field laid five and eight eggs. When handled, it may discharge from the cloaca $(\mathrm{N}=3)$, thrash the body $(\mathrm{N}=2)$, bite $(\mathrm{N}=2)$, and flatten the body $(\mathrm{N}=1)$.

21. Rhachidelus brazili Boulenger, 1908, "cobra preta", Figure 32

A large species (average $\mathrm{SVL}=905.7 \mathrm{~mm}$; range 391 to $1311 \mathrm{~mm} ; \mathrm{N}=41$ ), rarely found at the EEI and the Itirapina region. We found only one individual in an altered area outside the reserve, but it may occur inside the EEI, since after the regu-

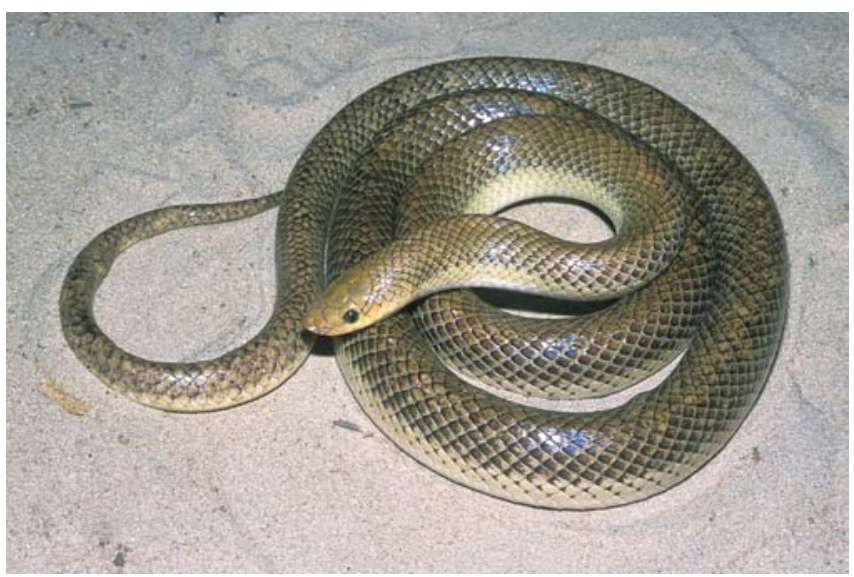

Figure 30. Phimophis guerini.

Figura 30. Phimophis guerini.

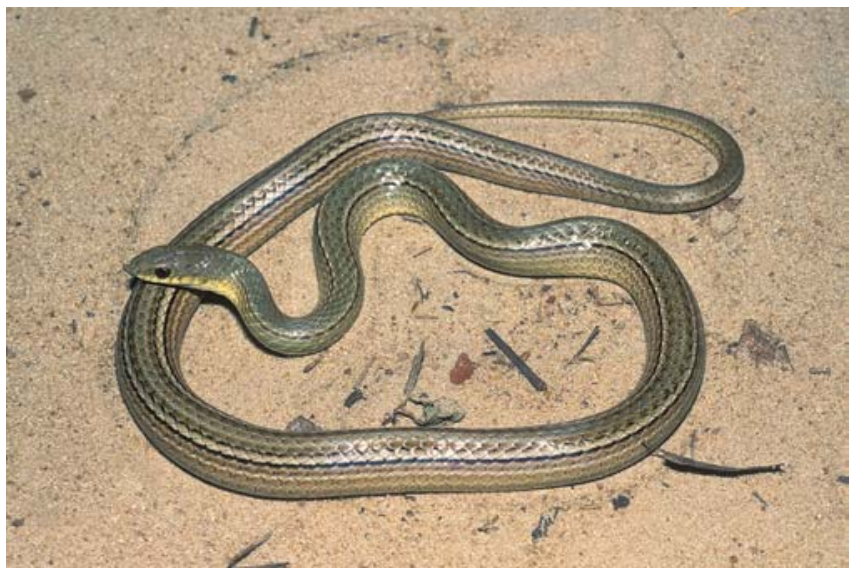

Figure 31. Pseudablabes agassizii.

Figura 31. Pseudablabes agassizii. 


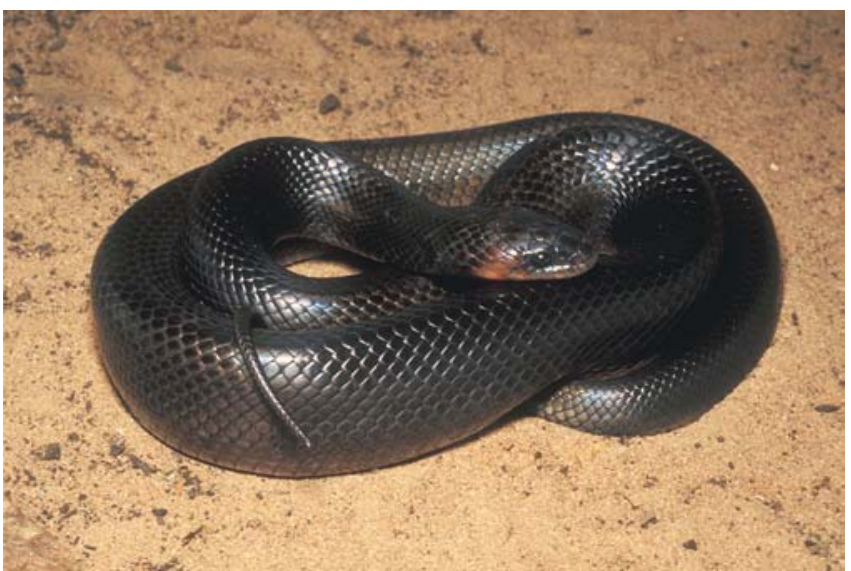

Figure 32. Rhachidelus brazili.

Figura 32. Rhachidelus brazili.

lar sampling we found one individual on a train track within the limits of the reserve. It seems to be mainly terrestrial (O. A. V. Marques, pers. obs.). The two individuals were found in October and November around 9:00 PM and 6:00 PM, respectively. Its diet consists almost exclusively of bird eggs, although birds and bird hatchlings can also be preyed upon (Marques et al., unpublished data). It is an oviparous species, but detailed information on its reproduction is not available.

22. Sibynomorphus mikani (Schlegel 1837), “dormideira”, Figure 33

A small species (average $\mathrm{SVL}=361.7 \mathrm{~mm}$; range 135 to $580 \mathrm{~mm} ; \mathrm{N}=198$ ), rarely found at the EEI but found with intermediate frequency in altered areas outside the reserve. We found only one individual inside the reserve, at the border of the gallery forest. We found 18 individuals in altered areas outside the reserve. It is a terrestrial species. It was found throughout the year, but mainly in October $(\mathrm{N}=8)$. It was found at night $(\mathrm{N}=4)$ and during daytime $(\mathrm{N}=2)$. Its diet is specialized in slugs (Gastropoda Pulmonata; Oliveira 2001). It is an oviparous species that produces three to nine eggs, from August to January (Laporta-Ferreira et al. 1986).

23. Simophis rhinostoma (Schlegel 1837), "falsa coral", Figure 34

A moderate-sized species (average $\mathrm{SVL}=507.5 \mathrm{~mm}$; range 240 to $765 \mathrm{~mm} ; \mathrm{N}=54$ ), rarely found at EEI, but captured with intermediate frequency in Itirapina region. We found only four individuals inside the EEI, all of them in campo sujo. We found 13 individuals in altered areas outside the reserve. It is a terrestrial species. It was found from September to April, especially in December $(\mathrm{N}=5)$. It was found active only by day $(\mathrm{N}=4$; see also Sazima \& Abe 1991). Its diet is specialized on anurans (Physalaemus spp., Bizerra et al. 1994). It is an oviparous species that produces two to seven eggs (Jordão \& Bizerra 1996). Secondary vitelogenesis occurs from October to April, and eggs were recorded in October, November, and April in oviducts, when egg laying may occur (Jordão \& Bizerra 1996). Besides making an S-coil, and usually biting, it may vibrate the tail against the ground when disturbed (Sazima \& Abe 1991), especially in darker conditions (Marques 2001). Its color pattern (composed of red, black, and white rings arranged in triads), and most of its defensive tactics (cf. Sazima \& Abe 1991) are very similar to those exhibited by Micrurus frontalis (see Figures 34 and 39), which also occurs at the EEI. Thus, S. rhinostoma can be con-

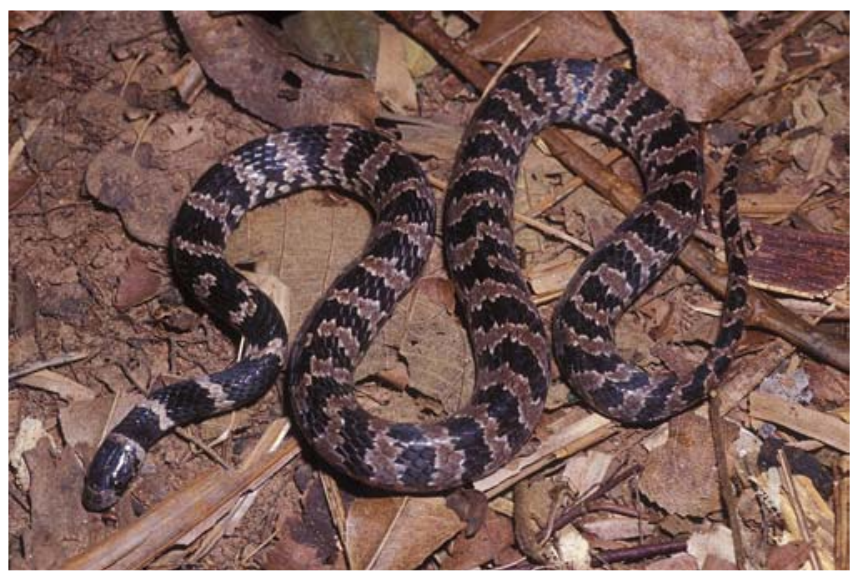

Figure 33. Sibynomorphus mikani (São Paulo, SP; photo: O. A. V. Marques).

Figura 33. Sibynomorphus mikani (São Paulo, SP; foto: O. A. V. Marques).

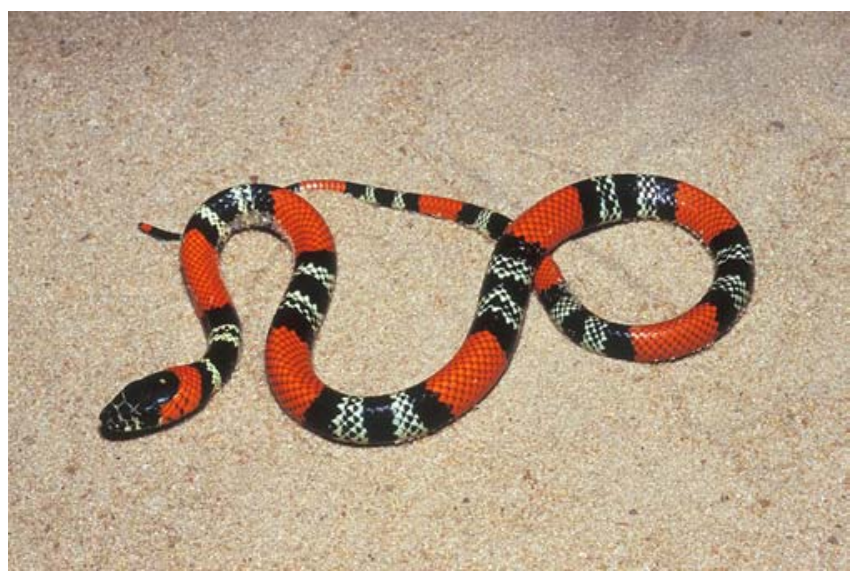

Figure 34. Simophis rhinostoma.

Figura 34. Simophis rhinostoma.

sidered as a very precise mimic of $M$. frontalis (Sazima \& Abe 1991, Marques 2001).

24. Taeniphallus occipitalis (Jan 1863), “cobra capim”, Figure 35

A small species (average $\mathrm{SVL}=296.9 \mathrm{~mm}$; range 140.5 to $399 \mathrm{~mm} ; \mathrm{N}=27$ ), found with intermediate frequency at the EEI. We found individuals in almost all cerrado physiognomic forms, like campo cerrado $(\mathrm{N}=5)$, campo sujo $(\mathrm{N}=4)$, and the border of gallery forest $(\mathrm{N}=2)$. We found one individual in a cerrado sensu stricto area outside the reserve. We did not find any individuals in altered areas. It seems to occur in different cerrado physiognomic forms, as observed in central Brazil (França et al. 2008). It is apparently terrestrial and cryptozoic. It is more active during the rainy season, from October to March $(\mathrm{N}=9)$, but we found some individuals active in August $(\mathrm{N}=1)$ and September $(\mathrm{N}=2)$. It is probably a diurnal species, as we found one individual resting at 8:58 PM, and another one active at 2:20 PM. The only prey known is a lizard found in the gut of a specimen captured in a grassland in Rio Grande do Sul state (Cechin 1999). It is an oviparous species, but detailed information on its reproduction is not available. 


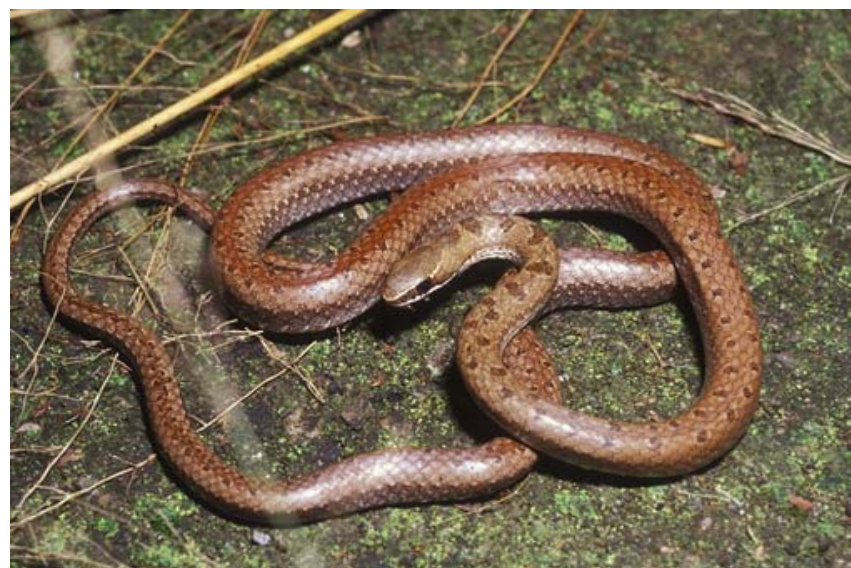

Figure 35. Taeniophalus occipitalis (photo: O. A. V. Marques).

Figura 35. Taeniophalus occipitalis (foto: O. A. V. Marques).

25. Tantilla melanocephala (Linnaeus 1758), "cobra da terra”, Figure 36

A small species (average $\mathrm{SVL}=198.7 \mathrm{~mm}$; range 97 to $293 \mathrm{~mm} ; \mathrm{N}=44$ ), frequently found at the EEI. We found individuals mainly in campo cerrado $(\mathrm{N}=29)$, but also at the border of the gallery forest $(\mathrm{N}=12)$, in campo sujo $(\mathrm{N}=6)$, and in altered areas outside the reserve $(\mathrm{N}=5)$. It is a cryptozoic and terrestrial species (Marques \& Puorto 1998). It was found active throughout the year, except in June, but it was more common in December $(\mathrm{N}=13)$, January $(\mathrm{N}=10)$, and March $(\mathrm{N}=10)$. Diurnal $(\mathrm{N}=1)$ and nocturnal activity was recorded $(\mathrm{N}=2)$. In other localities it was also observed in activity during the day (Sazima \& Manzani 1995), but in captivity it showed mainly nocturnal activity (Marques \& Puorto 1998). One individual was observed while being preyed upon by a Burrowing Owl, Speotyto cunicularia (Aves, Strigidae) at 7:24 PM (Granzinoli \& Motta-Jr. 2003). Its diet is specialized on centipedes, mainly of the genus Otostigmus (Chilopoda, Scolopendromorpha; Marques \& Puorto 1998). It is an oviparous species which produces one to three eggs, two on average ( $\mathrm{N}=19$; Marques \& Puorto 1998). The reproduction is seasonal with secondary vitellogenesis and ovulation limited to September and January (Marques \& Puorto 1998). When handled, it may thrash the body $(\mathrm{N}=6)$ and discharge from the cloaca $(\mathrm{N}=4)$.

26. Thamnodynastes hypoconia (Cope 1860), "jararaca dourada", Figure 37

A small species (average $\mathrm{SVL}=376.2 \mathrm{~mm}$; range 88 to $530 \mathrm{~mm} ; \mathrm{N}=203$ ), frequently found at the EEI. We found individuals only in riparian areas like the border of gallery forest $(\mathrm{N}=16)$, marshes $(\mathrm{N}=12)$, and in a temporary pond in campo sujo $(\mathrm{N}=3)$. We did not find any individuals in altered areas outside the reserve. Like its congenerics (cf. Bernarde et al. 2000), it is a semiarboreal species, being found mainly on the ground $(\mathrm{N}=12)$ and less often on the vegetation $(\mathrm{N}=4)$. It was found in activity only at night $(\mathrm{N}=15)$ and mainly from January to March. Its diet seems to be specialized on anurans $(\mathrm{N}=10)$. One individual was observed trying to subdue an adult individual of Elachistocleis ovalis (Microhylidae) head first; the frog inflated the body and escaped after a few minutes. It is a viviparous species that produces one to eight embryos, five on average $(\mathrm{N}=47)$. Secondary vitellogenesis occurs from January to September, the

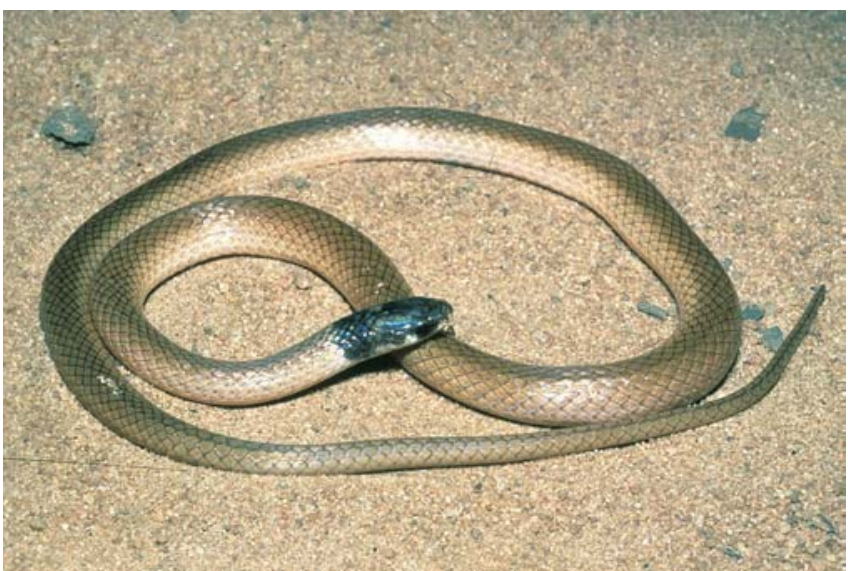

Figure 36. Tantilla melanocephala.

Figura 36. Tantilla melanocephala.

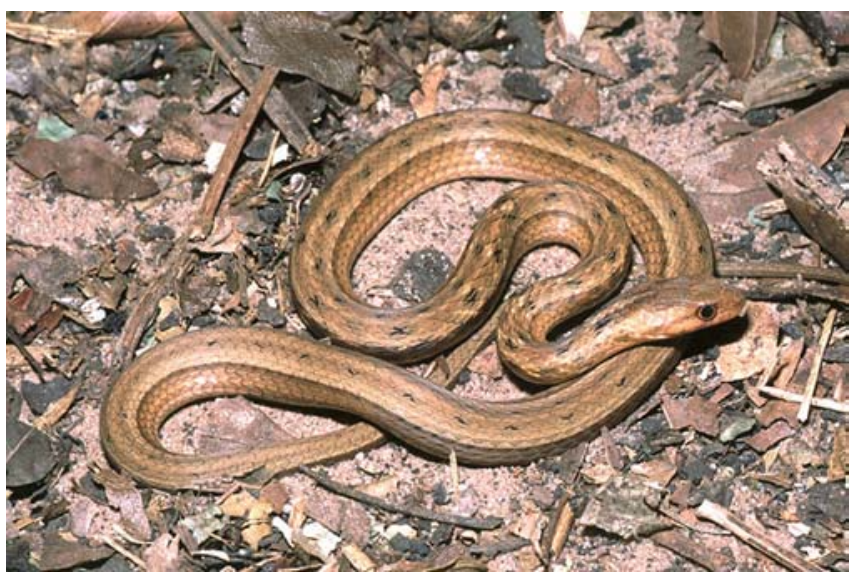

Figure 37. Thamnodynastes hypoconia.

Figura 37. Thamnodynastes hypoconia.

ovulation from March to November, and embryos are present from May to November, when births must occur (W. Ariedi-Jr., R. J. Sawaya, unpublished data). When handled, it may bite $(\mathrm{N}=7)$, gape its mouth $(\mathrm{N}=6)$, thrash the body $(\mathrm{N}=6)$, discharge from the cloaca $(\mathrm{N}=5)$, twist the body $(\mathrm{N}=5)$, strike $(\mathrm{N}=4)$, triangulate the head $(\mathrm{N}=4)$, and flatten the body $(\mathrm{N}=1)$.

27. Waglerophis merremii (Wagler 1824), "boipeva”, Figure 38

A moderate-sized species (average $\mathrm{SVL}=525.2 \mathrm{~mm}$; range 224 to $853 \mathrm{~mm} ; \mathrm{N}=33$ ), rarely found at the EEI. We found only one individual (Figure 38) inside the EEI, in December at 10:30 PM, under a small termite mound in campo sujo. It is a terrestrial and diurnal species (Vitt 1983). Its diet is specialized on anurans, especially the genus Rhinella (Bufonidae; Vitt 1983, Jordão 1997). It is an oviparous species. In populations of São Paulo state, its reproduction is continuous, but vitellogenesis is concentrated from April to January (Jordão 1997).

\section{ELAPIDAE}

1. Micrurus frontalis (Duméril Bibron \& Duméril 1854), "coral verdadeira", Figure 39

A large species (average $\mathrm{SVL}=784.3 \mathrm{~mm}$; range 234 to $1425 \mathrm{~mm} ; \mathrm{N}=124)$, rarely found at the EEI. We found only 


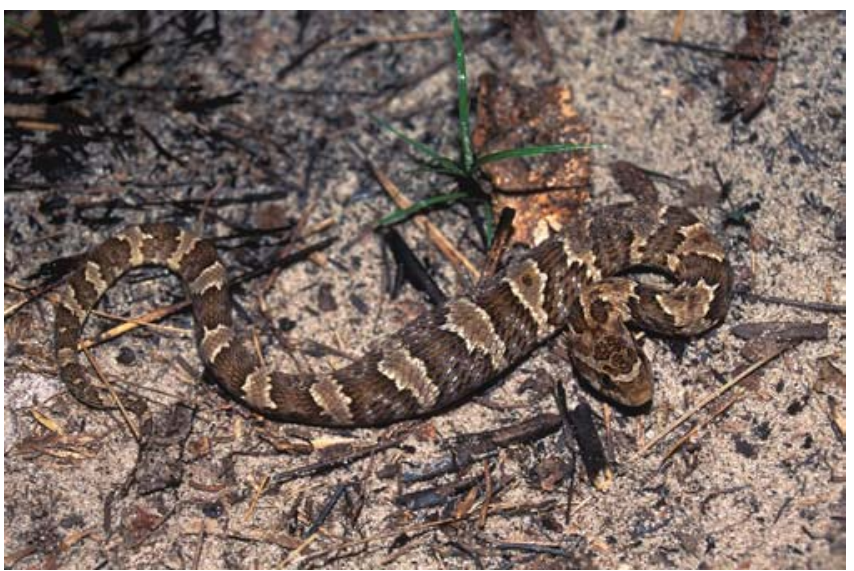

Figure 38. Waglerophis merremii (photo: M. Martins).

Figura 38. Waglerophis merremii (foto: M. Martins).

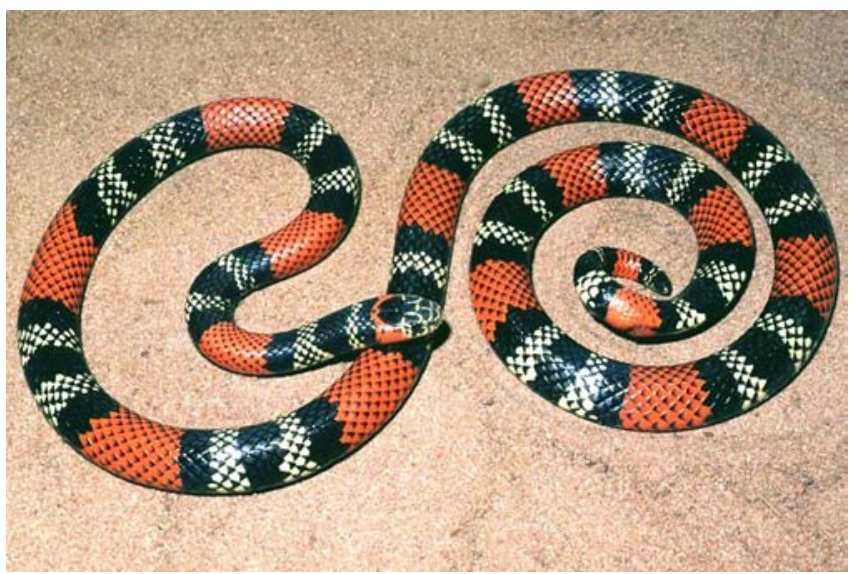

Figure 39. Micrurus frontalis (Campinas, SP).

Figura 39. Micrurus frontalis (Campinas, SP).

two individuals at the EEI: one inside a pitfall trap, in July, and another one moving on the ground, in September at 11:00 AM, both in campo sujo. We did not find any individuals in altered areas outside the reserve. It is a primarily fossorial species, probably diurnal and nocturnal (cf. Sazima \& Abe 1991), hardly seen on the surface. It feeds mainly on amphisbaenians (Sazima \& Abe 1991) but it also preys upon snakes (Greene 1973, O.A. V. Marques, pers. obs.). In southeastern Brazil, it also feeds on gymnophthalmid lizards, amphisbaenians, and caecilians as do other congenerics (Greene 1973, Marques \& Sazima 1997). It is an oviparous species; the secondary vitellogenesis begins in the dry season and eggs in the oviducts are found during the rainy season (O. A. V. Marques, pers. obs.).

\section{VIPERIDAE}

1. Bothrops alternatus Duméril Bibron \& Duméril, 1854, "urutu", Figure 40

A large species (average $\mathrm{SVL}=754.5 \mathrm{~mm}$; range 300 to $1240 \mathrm{~mm} ; \mathrm{N}=55$ ), frequently found at the EEI and the Itirapina region. We found individuals mainly in riparian areas $(\mathrm{N}=34)$, including the border $(\mathrm{N}=29)$ and interior $(\mathrm{N}=2)$ of gallery forests and marshes $(\mathrm{N}=3)$. It was also frequently found in campo sujo $(\mathrm{N}=23)$ and in altered areas outside the reserve $(\mathrm{N}=13)$. It was

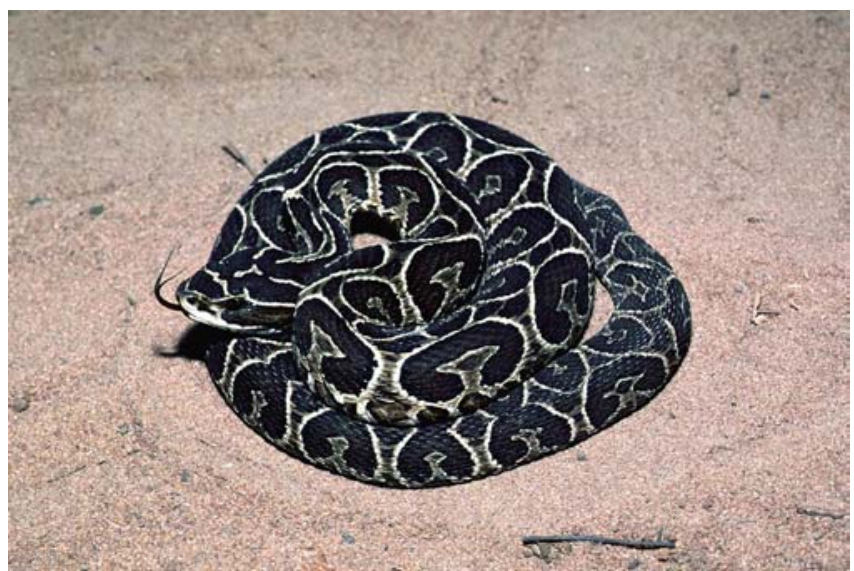

Figure 40. Bothrops alternatus.

Figura 40. Bothrops alternatus.

less frequently found in campo cerrado $(\mathrm{N}=7)$. Among cerrado Bothrops, it seems to be the major habitat generalist (cf. Nogueira 2001). It is a terrestrial species (Martins et al. 2001). It was found active throughout the year, but mainly in March $(\mathrm{N}=23)$. It was found active by day $(\mathrm{N}=23)$ and at night $(\mathrm{N}=14)$. It feeds exclusively on mammals (Martins et al. 2002). It is a viviparous species that produces one to 28 embryos (E. Haller, A. S. Abe, pers. comm.). Births may occur from the middle to the end of the rainy season (E. Haller, pers. comm.). As an observer approaches, this species may flee $(\mathrm{N}=6)$, face the observer $(\mathrm{N}=4)$, coil the body $(\mathrm{N}=2)$, flatten the body dorso-ventrally $(\mathrm{N}=2)$, vibrate the tail against the ground $(\mathrm{N}=2)$, strike $(\mathrm{N}=2)$, inflate the body $(\mathrm{N}=1)$, and move backwards with an S-coil $(\mathrm{N}=1)$. When restrained, it may strike $(\mathrm{N}=14)$, vibrate the tail against the ground $(\mathrm{N}=15)$, flatten the body $(\mathrm{N}=10)$, gape its mouth $(\mathrm{N}=5)$, discharge from the cloaca $(\mathrm{N}=4)$, thrash the body $(\mathrm{N}=2)$, hide the head $(\mathrm{N}=2)$, and inflate the body $(\mathrm{N}=1)$. We observed two instances and one attempt of predation on this species by the Burrowing Owl, Speotyto cunicularia (Martins et al. 2003). In the attempted predation, a young female that was stretched on an unpaved road coiled the body and hid the head after being attacked by the owl; as the observer approached, it struck twice and hid the head again (Martins et al. 2003).

2. Bothrops itapetiningae (Boulenger 1907), "jararaquinha”, Figure 41

A small species (average $\mathrm{SVL}=396.2 \mathrm{~mm}$; range 185 to $570 \mathrm{~mm} ; \mathrm{N}=89$ ), frequently found at the EEI. We found individuals mainly in campo sujo $(\mathrm{N}=29)$ and campo cerrado $(\mathrm{N}=17)$, and less frequently at the border of the gallery forest $(\mathrm{N}=4)$. Unlike its sympatric congenerics, it was not found in altered areas outside the reserve, thus it is very specialized regarding habitat use. Since there are very few remnants of open cerrado in São Paulo state, B. itapetiningae may be considered as a threatened species in this state (Sawaya 2004). The situation is not at all better in other parts of its range, such as Minas Gerais state (southeastern Brazil) and Brasilia region (central Brazil), where the species is restricted to very scattered small fragments like other grassland or open cerrado specialists (C. Nogueira, pers, comm.). It is a terrestrial species (Martins et al. 2001) and was found active virtually throughout the year, except in June, and mainly in February $(\mathrm{N}=11)$, March $(\mathrm{N}=10)$, and November $(\mathrm{N}=8)$. It was found active mainly at night $(\mathrm{N}=15)$, but it is also active during the day $(\mathrm{N}=7)$. It has a generalized diet, feeding on 
centipedes, anurans, lizards, birds, and mammals (Martins et al. 2002). It is viviparous, with vitellogenic ovarian follicles occurring from May to September (C. Nogueira, pers. comm.; RJS, pers. obs.). Females with embryos are found from October to December, when births may occur (C. Nogueira, pers. comm.). One female with four vitellogenic follicles was captured in 10 July 2001. With the observer's approach, it may flee $(\mathrm{N}=11)$, vibrate the tail against the ground $(\mathrm{N}=5)$, strike $(\mathrm{N}=5)$, face the observer $(\mathrm{N}=3)$, flatten the body dorso-ventrally $(\mathrm{N}=3)$, and inflate the body $(\mathrm{N}=1)$. When restrained, it may strike $(\mathrm{N}=21)$, flatten the body $(\mathrm{N}=18)$, vibrate the tail $(\mathrm{N}=16)$, hide the head $(\mathrm{N}=13)$, thrash the body $(\mathrm{N}=12)$, discharge from the cloaca $(\mathrm{N}=6)$, inflate the body $(\mathrm{N}=3)$, gape the mouth $(\mathrm{N}=2)$, and bite $(\mathrm{N}=1)$

3. Bothrops moojeni Hoge, 1966, "jararaca do brejo", Figure 42

A moderate-sized species (average $\mathrm{SVL}=631.1 \mathrm{~mm}$; range 280 to $1140 \mathrm{~mm} ; \mathrm{N}=52$ ), frequently found at the EEI. Like in other regions (Borges \& Araújo 1998), it was found mainly in riparian areas $(\mathrm{N}=43)$, including the border $(\mathrm{N}=24)$ and interior $(\mathrm{N}=2)$ of gallery forests and in marshes $(\mathrm{N}=17)$. It is relatively common also in altered areas outside the reserve $(\mathrm{N}=12)$, as also observed in other populations (Borges \& Araújo 1998). It was less frequent in open physiognomic forms like campo cerrado $(\mathrm{N}=4)$ and campo sujo $(\mathrm{N}=2)$. It is a semiarboreal species (Martins et al. 2001), but it was found more frequently on the ground $(\mathrm{N}=32)$ than on the vegetation $(\mathrm{N}=4)$. It was active throughout the year, except in May and August, and mainly in October and March $(\mathrm{N}=53)$. It was found active mainly at night $(\mathrm{N}=44)$, but also during daytime $(\mathrm{N}=7)$. Its diet is generalized, including centipedes, anurans, lizards, snakes, birds, and mammals (Martins et al. 2002, Nogueira et al. 2003). It is a viviparous species that produces from three to 32 embryos, 16 on average ( $N=21$; Nogueira et al. 2003). Reproduction is seasonal with ovulation around July and births are probably concentrated in December and January (Nogueira et al. 2003). As an observer approaches, it may flee $(\mathrm{N}=21)$, vibrate the tail against the ground $(\mathrm{N}=3)$, gape its mouth $(\mathrm{N}=2)$, face the observer $(\mathrm{N}=1)$, flatten the body dorso-ventrally $(\mathrm{N}=1)$, and strike $(\mathrm{N}=1)$. When restrained, it may vibrate the tail $(\mathrm{N}=19)$, twist the body $(\mathrm{N}=18)$, gape the mouth $(\mathrm{N}=11)$, discharge from the cloaca $(\mathrm{N}=11)$, strike $(\mathrm{N}=10)$, bite $(\mathrm{N}=10)$, thrash the body $(\mathrm{N}=7)$, and hide the head $(\mathrm{N}=2)$.

4. Bothrops pauloensis Amaral, 1925, “jararaca pintada”, Figure 43

A moderate-sized species (average $\mathrm{SVL}=560.8 \mathrm{~mm}$; range 188 to $895 \mathrm{~mm}$; $\mathrm{N}=61$ ), rarely found at the EEI but found with intermediate frequency in the Itirapina region. We found individuals mainly in altered areas outside the reserve $(\mathrm{N}=11)$. Inside the reserve we found individuals in campo cerrado $(\mathrm{N}=2)$ and campo sujo $(\mathrm{N}=1)$. It is a terrestrial species (Martins et al. 2001, Valdujo et al. 2002). It was found active in February $(\mathrm{N}=3)$, March $(\mathrm{N}=1)$, May $(\mathrm{N}=1)$, July $(\mathrm{N}=1)$, October $(\mathrm{N}=1)$, November $(\mathrm{N}=3)$, and December $(\mathrm{N}=4)$. We found it active both at night $(\mathrm{N}=3)$ and during daytime $(\mathrm{N}=3)$. Its diet is generalized, including centipedes, anurans, lizards, snakes, birds, and mammals (Martins et al. 2002, Valdujo et al. 2002). It is a viviparous species that gives birth to four to 20 young, nine on average ( $\mathrm{N}=15$; Valdujo et al. 2002). Reproduction is seasonal, with secondary vitellogenesis and ovulation beginning probably in March, and recruitment concentrated from October to December (Valdujo et al. 2002). When restrained, it may strike $(\mathrm{N}=1)$.

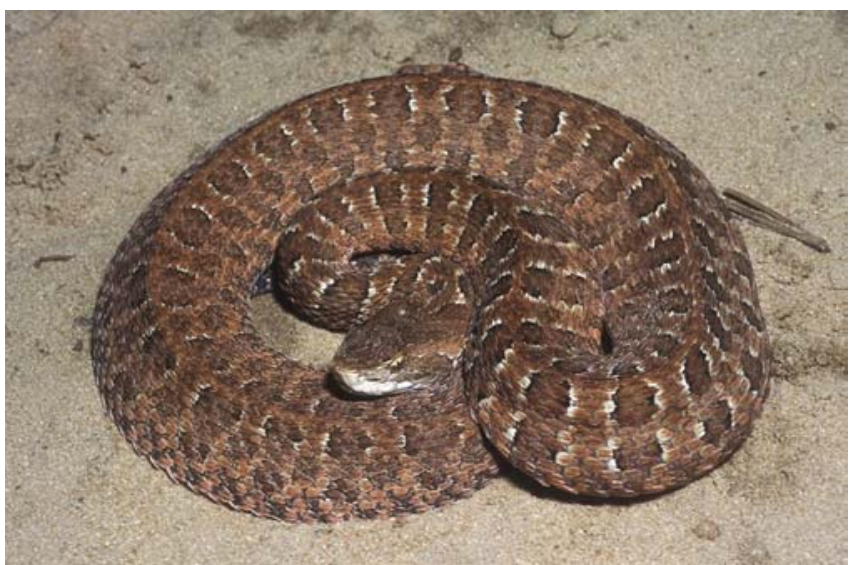

Figure 41. Bothrops itapetiningae (photo: M. Martins).

Figura 41. Bothrops itapetiningae (foto: M. Martins).

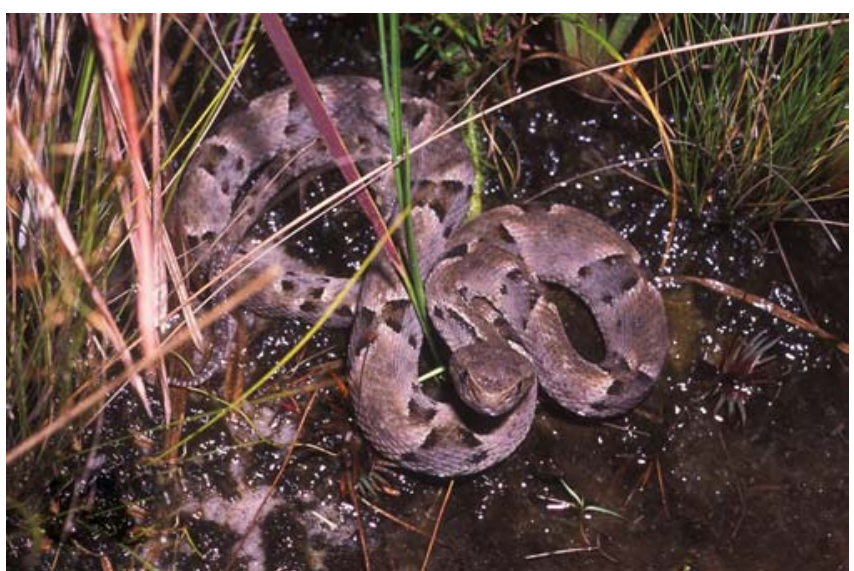

Figure 42. Bothrops moojeni (photo: M. Martins).

Figura 42. Bothrops moojeni (foto: M. Martins).

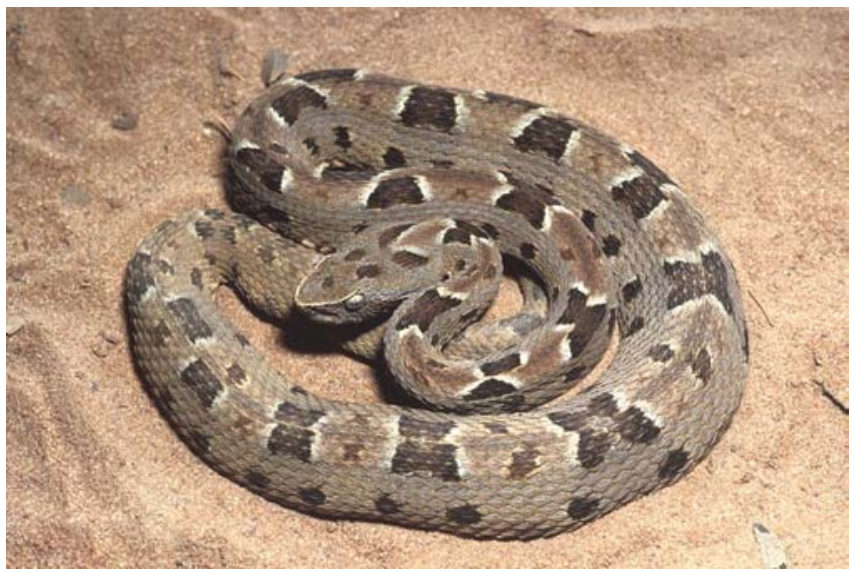

Figure 43. Bothrops pauloensis.

Figura 43. Bothrops pauloensis.

5. Crotalus durissus (Laurenti 1768), "cascavel”, Figures 44 and 45

A large species (average $\mathrm{SVL}=662.1 \mathrm{~mm}$; range 177 to 1405 $\mathrm{mm} ; \mathrm{N}=70$ ), the most frequently found species in the EEI and the Itirapina region. We found individuals mainly in campo sujo 


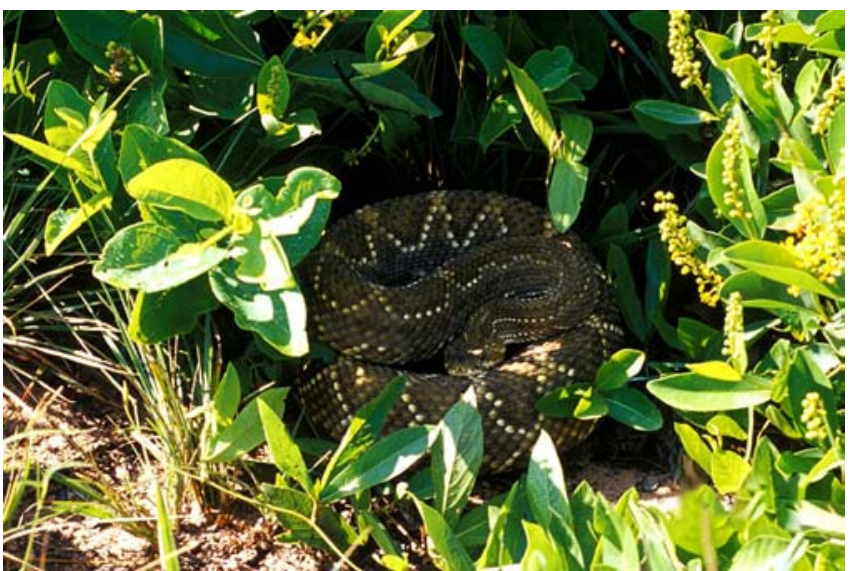

Figure 44. Crotalus durissus.

Figura 44. Crotalus durissus.

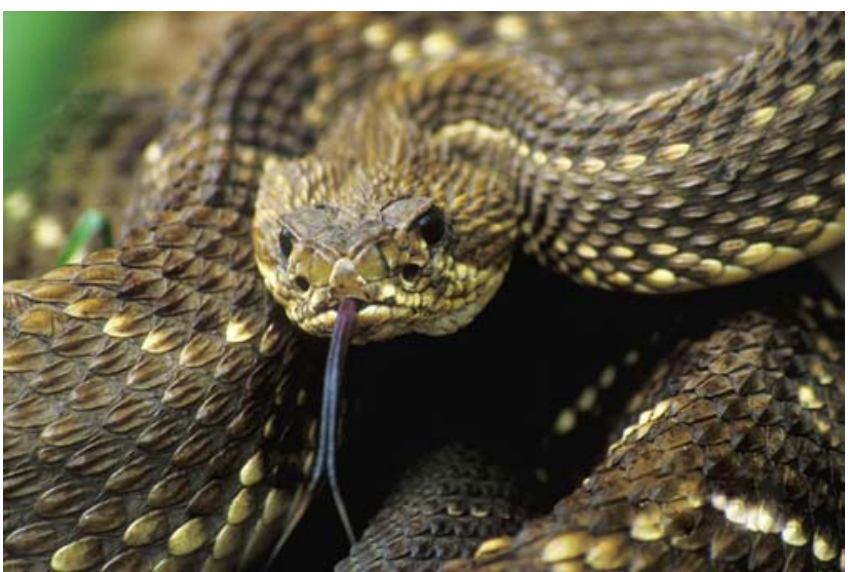

Figure 45. Crotalus durissus (photo: A. Tozetti).

Figura 45. Crotalus durissus (foto: A. Tozetti).

$(\mathrm{N}=32)$, but also in campo cerrado $(\mathrm{N}=14)$, and riparian areas $(\mathrm{N}=24)$, including the border of the gallery forest $(\mathrm{N}=21)$ and marshes $(\mathrm{N}=3)$. It was the most frequently captured species in altered areas outside the reserve $(\mathrm{N}=37)$. It is a terrestrial species. It was active throughout the year, being more abundant during the rainy season, from October to March $(\mathrm{N}=76)$, and mainly in February $(\mathrm{N}=18)$ and March $(\mathrm{N}=23)$. The seasonal activity concentrated at the end of the rainy season is probably due to the occurrence of mating and combat between males (cf. Salomão et al. 1995, Almeida-Santos \& Orsi 2002). It was found active both by day $(\mathrm{N}=36)$ and night $(\mathrm{N}=28)$. Its diet is specialized in mammals, but it may feed on lizards occasionally (Sant'anna 1999, Almeida-Santos \& Germano 1996, Hoyos 2006). It is viviparous. Vitellogenesis lasts long, beginning in March, with pregnancy from October to January, and juvenile recruitment from January to March (Almeida-Santos \& Salomão 1997, Almeida-Santos \& Orsi 2002). As an observer approaches, it may flee $(\mathrm{N}=16)$, face the observer $(\mathrm{N}=9)$, rattle $(\mathrm{N}=5)$, and coil the body $(\mathrm{N}=3)$. In general, it rattles only when the observer is close (about one meter or less). When restrained, it may rattle $(\mathrm{N}=18)$, strike $(\mathrm{N}=13)$, discharge from the cloaca $(\mathrm{N}=12)$, gape its mouth $(\mathrm{N}=10)$, shake the body $(\mathrm{N}=4)$, bite
$(\mathrm{N}=3)$, discharge secretion from the cloacal gland in flushes $(\mathrm{N}=3)$, flatten the body $(\mathrm{N}=2)$, and twist the body $(\mathrm{N}=2)$. On two occasions, adult males restrained in plastic transparent tubes discharged secretion from the cloacal glands towards the observer's face. The secretion had a strong smell and caused nausea and pain in mouth and eyes, indicating it could be an important defensive tactic (but see Salomão et al. 2002).

\section{Discussion}

The Itirapina region probably presents an even higher richness of Cerrado snake species than the one we obtained. Snakes are relatively difficult to sample because they usually occur in low densities (compared to lizards, for instance), most species are cryptic, and many have secretive habits (Sazima \& Haddad 1992). Thus, even considering the great sampling effort, more than three and a half years of sampling, 446 fieldwork days, and the combination of six sampling methods, we probably did not record all snake species that occur in the region.

The species composition of Itirapina is similar to that of open habitats, like other Cerrado, Caatinga, Pampa, and Pantanal assemblages (Figures 2 and 3). Interestingly, the snake fauna from two Atlantic Forest assemblages seems to be more related to that of open formations in central and southern Brazil than to the two Amazon localities, despite the higher structural similarity between the Atlantic Forest and the Amazon (Figures 2 and 3).The relationships among the Atlantic Forest assemblages to those of the Cerrado and other open formations south of the Amazon probably reflect the distribution patterns of different lineages of Neotropical colubrids (cf. Cadle \& Greene 1993), including the higher diversity of South American xenodontines south of the Amazon and a higher diversity of colubrines and Central American xenodontines (Dipsadines) in the Amazon. Therefore, historical factors, such as biogeography, seem to be more important in determining the composition of the assemblages analyzed here, than the structure of the habitats in which they occur (e.g., forest versus open habitats), or even the geographic distance (Figures 1, 2, and 3).

The three Cerrado assemblages were grouped together in the multivariate analysis, indicating that the Cerrado shows particular characteristics regarding species composition. When comparing the Cerrado and the Caatinga lizard assemblages, Vanzolini $(1976,1988)$ concluded that those two biomes did not show characteristic faunas, and that the similarity between those faunas is related to a corridor of open areas from northwestern Argentina to northeastern Brazil. However, Colli et al. (2002) suggest that this generalization is related to inadequate sampling and/or analysis. These authors also discuss that, unlike previously suggested in the literature, the Cerrado harbors a large number of endemic species, including at least 11 endemic snakes. The composition of the still poorly studied Cerrado snake assemblages is still enigmatic. However, two elements suggest that the Cerrado is a cohesive biome with regard to snake assemblages: 1) the relatively high rate of endemism; and 2) the clustering of the three Cerrado localities in the Principal Coordinates Analysis.

The Estação Ecológica de Itirapina is a relatively small fragment (about 2,300 ha), despite showing well preserved and representative Cerrado physiognomic forms. In the vicinities of the reserve, the Cerrado remnants are similarly or more fragmented and/or in advanced stages of anthropogenic disturbance. Even so, the region shows a rich and typical Cerrado snake fauna. The occurrence of some species only inside the reserve also indicates that the Estação Ecológica de Itirapina is of fundamental importance to the maintenance of the Cerrado biodiversity. 


\section{Acknowledgements}

We are grateful to Instituto Florestal from São Paulo state, especially Denise Zanchetta, for permission to work at the Estação Ecológica de Itirapina and for providing logistical support. We also thank Instituto Brasileiro do Meio Ambiente e dos Recursos Naturais Renováveis (IBAMA) for the permit to collect specimens (02027.010426/99-21). This work was possible only with the generous help of several people during field work. In this sense, we are very grateful mainly to Felipe Spina, Carol Monteiro, Vagner Ariedi-Jr., Alexandro Tozetti, Glauco Machado, Vinicius Bonato, Eduardo G. Martins, Graziella Giraldelli, Luciano dos Anjos, Gilson Gianez, J. Clóvis Buzo, Paulo R. Manzani, and, especially, Cínthia A. Brasileiro, Mara C. Kiefer, and M. Ermelinda Oliveira. We also thank Vagner Ariedi-Jr., Cinthia A. Brasileiro, Jivanildo Miranda, Ligia Pizzatto, Fernanda Stender-Oliveira, M. Ermelinda Oliveira, Luciano dos Anjos, and Daniela F. Bertani for help in laboratory work. Ligia Pizzatto, Cristiano Nogueira, Paula Valdujo, Juliana Lima, and Érika Haller kindly provided unpublished data. We thank Fausto Barbo for the map. Ivan Sazima, Augusto Abe, Guarino Colli, and Glauco Machado made very useful suggestions on previous drafts of the manuscript. We also thank Cristiano Nogueira and Bob Thomas for the careful revision on a previous draft of the manuscript that improve substantially the quality of our work. R. J. Sawaya thanks the Fundação de Amparo à Pesquisa do Estado de São Paulo (FAPESP) for a PhD fellowships, and the graduate program in Ecology, the Departamento de Zoologia and the Museu de História Natural of the Universidade Estadual de Campinas for the logistical support. Most of the fieldwork was funded by FAPESP and Conselho Nacional de Desenvolvimento Científico e Tecnológico (CNPq). Additional funding was provided by the graduate program in Ecology, Instituto de Biociências, Universidade de São Paulo. M. Martins and O. A. V. Marques thank CNPq for the providential research fellowships. This is publication number 29 of the project "Ecology of the Cerrados of Itirapina".

\section{References}

ALBOLEA, A.B.P. 1998. Padrões de atividade em serpentes não peçonhentas de interesse médico: Helicops modestus (Colubridae: Xenodontinae) e Liophis miliaris (Colubridae: Xenodontinae) e sua relação com a epidemiologia. Dissertação de Mestrado, Universidade de Guarulhos, Guarulhos.

ALMEIDA-SANTOS, S.M. \& GERMANO, V.J. 1996. Crotalus durissus (Neotropical Ratlesnake). Prey. Herpetol. Rev. 27(3):255-255.

ALMEIDA-SANTOS, S.M. \& ORSI, A.M. 2002. Ciclo reprodutivo de Crotalus durissus e Bothrops jararaca (Serpentes Viperidae): morfologia e função dos ovidutos. Rev. Bras. Reprod. Anim. 26:109-112.

ALMEIDA-SANTOS, S.M. \& SALOMAO, M.G. 1997. Long term sperm storage in the female neotropical rattlesnake Crotalus durissus terrificus (Viperidae: Crotalidae). Japan. J. Herpetol. 17:46-52.

ANDRADE, R.O. \& SILVANO, R.A.M. 1996. Comportamento alimentar e dieta da "Falsa-Coral" Oxyrhopus guibei Hoge \& Romano (Serpentes Colubridae). Rev. Bras. Zool. 13(1):143-150.

ARGÔLO, A.J.S. 1992. Considerações sobre a ofiofauna dos cacauais do sudeste da Bahia. Dissertação de mestrado, Universidade Estadual Santa Cruz, Santa Cruz.

BERNARDE, P.S., KOKUBUM, M.N. \& MARQUES, O.A.V. 2000. Utilização de hábitat e atividade em Thamnodynastes strigatus (Günther 1958) no sul do Brasil (Serpentes, Colubridae). Bol. Mus. Nac., Zool. 428:1-8.

BERNARDE, P.S. \& ABE, A.S. 2006. A snake community at Espigão do Oeste, Rondônia, southwestern Amazon, Brazil. South American Journal of Herpetology 1(2): 102-113.
BIZERRA, A.F., JORDÃO, R.S. \& SAZIMA, I. 1994. Simophis rhinostoma (NCN). Diet. Herpetol. Rev. 25(2): 72-73.

BORGES, R.C. \& ARAUJO, A.F.B. 1998. Seleção de hábitat em duas espécies de jararacas (Bothrops moojeni Hoge e B. neuwiedi Wagler). Rev. Bras. Biol. 58(4): 489-493.

BRASILEIRO, C.A., MARTINS, M. \& KIEFER, M.C. 2003. Lystrophis nattereri (NCN). Predation. Herpetol. Rev. 34(1): 70-70.

BRASIlEIRO, C.A., SAWAYA, R.J., KIEFER, M.C., MARTINS, M. 2005. Anfíbios de um fragmento de Cerrado aberto do sudeste do Brasil. Biota Neotrop. 5(2): http://www.biotaneotropica.org.br/v5n2/pt/ abstract?article+BN00405022005 (último acesso em 26/06/2008).

BRITES, V.L.C. \& BAUAB, F.A. 1988. Fauna ofidiana do município de Uberlândia Minas Gerais - Brasil. I. Ocorrência na área urbana. Rev. Cent. Ciênc. Bioméd. Univ. Fed. Uberlândia 4: 3-8.

BRODIE, E.D. III. 1993. Differential avoidance of coral snake banded patterns by free-ranging avian predators in Costa Rica. Evolution 47(1): 227-235.

CADLE, J.E. \& GREENE, H.W. 1993. Phylogenetic patterns biogeography and the ecological structure of Neotropical snake assemblages. In Species diversity in ecological communities: historical and geographical perspectives (E. Ricklefs \& D. Schluter, eds). University of Chicago Press, Chicago, p. 281-293.

CAMPBELL, H.W. \& CHRISTMAN, S.P. 1982. Field techniques for herpetofaunal community analysis. In Herpetological Communities: a Symposium of the Society for the Study of Amphibians and Reptiles and the Herpetologist's League (N.J. Scott-Jr., ed.). U.S. Fish Wild. Serv. Wildl. Res. Rep. 13, p.193-200.

CARVALHO, M.A. \& NOGUEIRA, F. 1998. Serpentes da área urbana de Cuiabá Mato Grosso: aspectos ecológicos e acidentes ofídicos associados. Cad. Saúde Pública Rio de Janeiro 14(4):753-763.

CASSIMIRO, J., BERTOLUCI, J. \& MARTINS, W.P. 2002. Atractus pantostictus (Fura-terra). Clutch Size. Herpetol. Rev. 33(2): 137-137.

CECHIN, S.Z. 1999. História natural de uma comunidade de serpentes na região da depressão central (Santa Maria) Rio Grande do Sul, Brasil. Tese de Doutorado, Pontífica Universidade Católica do Rio Grande do Sul, Rio Grande do Sul.

CECHIN, S.Z. \& MARTINS, M. 2000. Eficiência de armadilhas de queda (Pitfall traps) em amostragens de anfíbios e répteis no Brasil. Rev. Bras. Zool. 17(3):729-749.

CEI, J.M. 1993. Reptiles del noroeste nordeste y este de la Argentina. Herpetofauna de lãs selvas subtropicales Puna y Pampas. Museo Regionale di Scienze Naturali, Torino.

COLLI, G.R., BASTOS, R.P. \& ARAUJO, A.F.B. 2002. The character and dynamics of the Cerrado herpetofauna. In The Cerrados of Brazil: Ecology and natural history of a Neotropical Savanna (P.S. Oliveira \& R.J. Marquis, eds). Columbia University Press, New York, p. 223-241.

COSTA, C.C. 1979. Répteis. In Fauna do cerrado: lista preliminar de aves mamíferos e répteis. Fundação Instituto Brasileiro de Geografia e Estatística SRNMA, São Paulo.

COSTA, G.C., NOGUEIRA, C., MACHADO, R.B. \& COLLI, G.R. 2007. Squamate richness in the Brazilian Cerrado and its environmental-climatic associations. Divers. Distrib. 13(6): 714-724.

CUNHA, O.R. \& NASCIMENTO, F.P. 1978. Ofídios da Amazônia X - As cobras da região leste do Pará. Publicações Avulsas do Museu Paraense Emílio Goeldi 31: 1-218.

DI-BERNARDO, M. 1998. História Natural de uma comunidade de serpentes da borda oriental do planalto das Araucárias Rio Grande do Sul Brasil. Tese de Doutorado, Universidade Estadual Paulista, Rio Claro, São Paulo.

DIXON, J.R. 1980. The neotropical colubrid snake genus Liophis. The generic concept. Contributions in Biology and Geology, Milwaukee Public Museum, Milwaukee, p. 31-38.

DIXON, J.R. \& MARKEZICH, A.L. 1992. Taxonomic and geographic variation of Liophis poecilogyrus (Weid) from South America (Serpentes: Colubridae). Texas J. Sci. 44(2):131-166. 
DIXON, J.R. \& SOINI, P. 1986. The Reptiles of the Upper Amazon Basin Iquitos region Peru. Milwaukee Public Museum, Milwaukee.

DIXON, J.R., WIEST-JR., J.A. \& CEI, J.M. 1993. Revision of the Neotropical Snake Genus Chironius Fitzinger (Serpentes Colubridae). Monografie XIII. Museo Regionale di Scienze Naturali, Torino.

DUELLMAN, W.E. 1989. Tropical herpetofaunal communities: patterns of community structure in Neotropical rainforests. In Vertebrates in Complex Tropical Systems (M.L. Harmelin-Vivien \& Bourliére, F. eds.). SpringerVerlag, New York, p. 61-88.

FERNANDES, D.F. 2006. Revisão sistemática de Liophis poecilogyrus (WiedNeuwied 1825) (Serpentes: Colubridae). Tese de doutorado, Universidade Federal do Rio de Janeiro, Rio de Janeiro.

FERNANDES, R. \& PUORTO, G. 1993. A new species of Atractus from Brazil and the status of $A$. guentheri (Serpentes: Colubridae). Memo. Inst. Butantan 55(1):7-14.

FOWLER, I.R. \& SALOMÃO, M.G. 1994. Activity patterns in the colubrid snake genus Philodryas and their relationship to reproduction and snake bite. Bull. Chicago Herp. Soc. 29(10):229-232.

FOWLER, I.R., SALOMÃO, M.G. \& JORDÃO, R.S. 1998. A description of the female reproductive cycle in four species from the neotropical colubrid snake Philodryas (Colubridae Xenodontinae). Snake 28(1-2):71-78.

FRANÇA, F.G.R. \& ARAÚJO, A.F.B. 2006. The conservation status of snakes in central Brazil. South American Journal of Herpetology 1(1):25-36.

FRANÇA, F.G.R., MESQUITA, D.O., NOGUEIRA, C.C. \& ARAÚJO, A.F.B. 2008. Phylogeny and Ecology Determine Morphological Structure in a Snake Assemblage in the Central Brazilian Cerrado. Copeia 1(2008): 23-38.

FROTA, J.G. 2005. Biologia reprodutiva e dieta de Liophis jaegeri jaegeri (Günther, 1858) (Serpentes, Colubridae, Xenodontinae). Dissertação de mestrado, Pontifícia Universidade Católica do Rio Grande do Sul, Rio Grande do Sul

GONZAGA, L.A.P., CASTIGLIONI, G.D.A. \& ALVES, M.A. 1997. Philodryas patagoniensis (NCN). Diet. Herpetol. Rev. 28(3):154-154.

GRANZINOLLI, M.A. \& MOTTA-JR, J.C. 2003. Tantilla melanocephala (Black-Headed Snake). Predation. Herpetol. Rev. 34(2):156-157.

GREENE, H.W. 1973. The food habits and feeding behavior of the new world coral snakes. Master dissertation, The University of Texas at Arlington, Arlington.

GREENE, H.W. 1994. Systematics and natural history foundations for understanding and conserving biodiversity. Am. Zool. 34(1): 48-56.

GREENE, H.W. \& LOSOS, J.B. 1988. Systematics, Natural History, and Conservation: Field Biologists Must Fight a Public-Image Problem. BioScience 38(7): 458-462

GREENE, H.W. 1997. Snakes. The Evolution of Mystery in Nature. University of California Press, California.

GREENBERG, C.H., NEARY, D.G. \& HARRIS, L.D. 1994. A comparison of herpetofaunal sampling effectiveness of pitfall single-ended and doubleended funnel traps used with drift fences. J. Herpetol. 28(3): 319-324.

HARTMANN, P.A. 2001. Hábito alimentar e utilização do ambiente em duas espécies simpátricas de Philodryas (Serpentes Colubridae) no sul do Brasil. Dissertação de mestrado, Universidade Estadual Paulista, Rio Claro.

HARTMANN, P.A. \& MARQUES, O.A.V. 2005. Diet and habitat use of two sympatric Philodryas (Colubridae) in South Brazil. Amphibia-Reptilia 26(2005): 25-31

HENDERSON, R.W. 1993. On the diets of some arboreal boids. Herpetol. Nat. Hist. 1(1): 91-96.

HENDERSON, R.W., MICUCCI, T.W.P., PUORTO, G. \& BOURGEOIS, R.W. 1995. Ecological correlates and patterns in the distribution of Neotropical boines (Serpentes: Boidae): a preliminary assessment. Herpetol. Nat. Hist. 3(1):15-27.

HILLIS, D.M. 1995. American molecular naturalist. Ecology 76(3): 1017-1018.
HOYOS, M.A. 2006. Ecologia da cascavel (Viperidae, Crotalus durissus) no Cerrado brasileiro. Dissertação de Mestrado, Universidade de Brasília, Brasília.

JORDÃO, R.S. \& BIZERRA, A.F. 1996. Reprodução dimorfismo sexual e atividade de Simophis rhinostoma (Serpentes Colubridae). Rev. Bras. Zool. 56(3): 507-512.

JORDÃO, R.S. 1997. Estudo comparativo da alimentação e da reprodução de Waglerophis merremii e Xenodon neuwiedii (Serpentes: Colubridae). Dissertação de mestrado, Instituto de Biociências Universidade de São Paulo, São Paulo.

KOVACH, W.L. 1999. MVSP - A multi-variate statistical package for windows ver. 3.1. Kovach computing Services, Penthraeth.

KRONKA, F.J.N., NALON, M.A. \& MATSUKUMA, C.K. 1993. Áreas de domínio do Cerrado no Estado de São Paulo. Secretaria do Meio Ambiente, São Paulo.

LAPORTA-FERREIRA, I.L., SALOMÃO, M.G. \& SAWAYA, P. 1986. Biologia de Sibynomorphus (Colubridae - Dipsadinae) - Reprodução e hábitos alimentares. Rev. Bras. Zool. 46(4):793-799.

LOPES, H.R. \& ABE, A.S. 1981. Aspectos da biologia reprodutiva em fêmeas de Helicops modestus (Serpentes Colubridae). Resumos das Comunicações Científicas do VIII Congresso Brasileiro de Zoologia, Universidade de Brasília, Brasília.

MACIEL, A.P. 2001. Ecologia e história natural da cobra-do-capim Liophis poecilogyrus (Serpentes: Colubridae) no Litoral Norte do Rio Grande do Sul Brasil. Dissertação de Mestrado, Universidade Federal do Rio Grande do Sul, Rio Grande do Sul.

MANLY, B.F.J. 1994. Multivariate Statistical Methods. A primer. Chapman \& Hall, London.

MARQUES, O.A.V. 1998. Composição Faunística História Natural e Ecologia de Serpentes da Mata Atlântica na Região da Estação Ecológica Juréia-Itatins São Paulo SP. Tese de Doutorado, Universidade de São Paulo, São Paulo.

MARQUES, O.A.V. 2000. Tail display of the false coral snake Simophis rhinostoma (Colubridae). Amphibia-Reptilia 22(1):127-129.

MARQUES, O.A.V., ABE, A.S. \& MARTINS, M. 1998. Estudo diagnóstico da diversidade de répteis do Estado de São Paulo. In Biodiversidade do Estado de São Paulo: síntese do conhecimento ao final do século XX. v.6. Vertebrados (R.M.C. CASTRO, ed.). FAPESP, São Paulo, p. 29-38.

MARQUES, O.A.V., ETEROVIC, A. \& ENDO, W. 2001. Seasonal activity of snakes in the Atlantic Forest in southeastern Brazil. Amphibia-Reptilia 22(1): 103-111.

MARQUES, O.A.V. \& PUORTO, G. 1998. Feeding reproduction and growth in the crowned snake Tantilla melanocephala (Colubridae) from southeastern Brazil. Amphibia-Reptilia 19(3): 311-318.

MARQUES, O.A.V. \& SAZIMA, I. 1997. Diet and feeding of the coral snake Micrurus corallinus from the Atlantic Forest of Brazil. Herpetol. Nat. Hist. 5(1): 88-93.

MARQUES, O.A.V., SAWAYA, R.J., STENDER-OLIVEIRA, F. \& FRANÇA, F.G.R. 2006. Ecology of the colubrid snake Pseudablabes agassizii in south-eastern South America. Herpetological Journal 16(1): 37-45.

MARTINS, M. 1994. História Natural e ecologia de uma taxocenose de serpentes em mata primária na região de Manaus, Amazônia Central, Brasil. Tese de Doutorado, Universidade Estadual de Campinas, Campinas.

MARTINS, M., ARAÚJO, M.S., SAWAYA, R.J. \& NUNES, R. 2001. Diversity and evolution of macrohabitat use body size and morphology in a monophyletic group of neotropical pitvipers (Bothrops). J. Zool. 254(2001): 529-538.

MARTINS, M., MARQUES, O.A.V. \& SAZIMA, I. 2002. Ecological and phylogenetics correlates of feeding Habits in neotropical pitvipers of the Genus Bothrops. In Biology of the Vipers (G.W. Schuett, M. Hoggren \& M.E. Douglas, eds). Eagle Mountain Publishing, Utah, p. 307-328.

MARTINS, M. \& OLIVEIRA, M.E. 1998. Natural history of snakes in forests of the Manaus region Central Amazonia Brazil. Herpetol. Nat. Hist. 6(2): 78-150 
MARTINS, M., SPINA, F., MONTEIRO, C., SAWAYA, R.J. \& ARIEDIJUNIOR, V.R. 2003. Bothrops alternatus (Urutu). Predation. Herpetol. Rev. 34(2): 147-148.

MYERS, N, MITTERMIER, R.A., MITTERMIER, C.G., FONSECA, G.A.B. \& KENT, J. 2000. Biodiversity hotspots for conservation priorities. Nature 403: 853-858.

NOGUEIRA, C. 2001. Ecologia histórica de Bothrops spp. (Serpentes: Viperidae: Crotalinae) simpátricas no Cerrado. Dissertação de mestrado, Universidade de São Paulo, São Paulo.

NOGUEIRA, C., SAWAYA, R.J. \& MARTINS, M. 2003. Ecology of Bothrops moojeni (Serpentes: Viperidae: Crotalinae) in the Brazilian Cerrado. J. Herpetol. 37(4): 653-659.

OLIVEIRA, J.L. 2001. Ecologia de três espécies de dormideira Sibynomorphus (Serpentes: Colubridae). Dissertação de mestrado, Universidade de São Paulo, São Paulo.

OLIVEIRA, R.B., DI-BERNARDO, M., PONTES, G.M.F., MACIEL, A.P. \& KRAUSE, L. 2001. Dieta e comportamento alimentar da cobra-nariguda Lystrophis dorbignyi (Duméril Bibron \& Duméril 1854) no litoral norte do Rio Grande do Sul Brasil. Cuad. Herpet. 14(2): 117-122.

PARMELEE, J.R. \& FITCH, H.S. 1995. An experiment with artificial shelters for snakes: effects of material age and surface preparation. Herpetol. Nat. Hist. 3(2): 187-191.

PASSOS, P.G.H. 2003. Sistemática do complexo E. cenchria (Linnaeus, 1978) com aproximações sobre filogenia de Epicrates Wagler, 1830 (Serpentes: Boidae). Dissertação de mestrado, Universidade Federal do Rio de Janeiro, Rio de Janeiro.

PETERS, J.A., OREJAS-MIRANDA, B. \& VANZOLINI, P.E. 1986. Catalogue of Neotropical Squamata. Smithsonian Institution Press, Washington and London.

PICCHI, S.H.A. 2001. Estudo antômico-topográfico e análise da biologia reprodutiva de Helicops modestus Günther 1861 (Colubridae Xenodontini). Dissertação de mestrado, Universidade de São Paulo, São Paulo.

PINTO, C.C. \& LEMA, T. 2002. Comportamento alimentar e dieta de serpentes do gênero Boiruna e Clelia. Iheringia 92(2): 9-19.

PIZZATTO, L. 2003. Reprodução de Liophis miliaris (Serpentes: Colubridae) no Brasil: influência histórica e variações geográficas. Dissertação de mestrado, Universidade Estadual de Campinas, Campinas.

PIZZATTO, L. 2006. Ecomorfologia e estratégias reprodutivas nos Boidae (Serpentes), com ênfase nas espécies Neotropicais. Tese de doutorado, Universidade Estadual de Campinas, Campinas.

PIZZATTO, L. \& MARQUES, O.A.V. 2002. Reproductive biology of the false coral snake Oxyrhopus guibei (Colubridae) from southeastern Brazil. Amphibia-Reptilia 23(4): 495-504.

PIZZATO, L., MANFIO, R.H. \& ALMEIDA-SANTOS, S.M. 2006. Malemale ritualized combat in the Brazilian rainbow boa, Epicrates cenchria crassus. Herpetol. Bull. 95:16-20.

PUORTO, G. \& FERRAREZZI, H. 1993. Uma nova espécie de Phalotris Cope 1862 com comentários sobre o grupo bilineatus (Serpentes: Colubridae: Xenodontinae). Memo. Inst. Butantan 55(1):39-46.

RATTER, J.A., RIBEIRO, J.F. \& BRIDGEWATER, S. 1997. The Brazilian Cerrado vegetation and threats to its biodiversity. Ann. Bot. 80(3): 223-230.

RICKLEFS, R.E. 1990. Ecology. Freeman. \& and Company, New York.

SALOMÃO, M.G., ALMEIDA-SANTOS, S.M., PUORTO, G. 1995. Activity pattern of Crotalus durissus (Viperidae Crotalinae): feeding reproduction and snakebite. Stud. Neotrop. Fauna Environ. 30(2):101-106.

SALOMÃO, M.G., ALMEIDA-SANTOS, S.M., ANTONIAZZI, M.M., PUORTO, G. \& JARED, C. 2002. Glândulas Anais de Crotalus durissus terrificus (Viperidae: Crotalinae): Defesa ou Reprodução? In Livro de Resumos do XXIV Congresso Brasileiro de Zoologia, XXIV Congresso Brasileiro de Zoologia, Itajaí, p.427.
SANT'ANNA, S. 1999. Hábito alimentar da cascavel Crotalus durissus no sudeste brasileiro (Serpentes Viperidae). Tese de doutorado, Universidade Estadual Paulista, Rio Claro.

SAVAGE, J.M. \& SLOWINSKY, J.B. 1992. The colouration of the venomous coral snakes (family Elapidae) and their mimics (families Aniliidae and Colubridae). Biol. J. Linn. Soc. 45(3): 235-254.

SAVITZKY, A.H. 1979. The origin of the New World proteroglyphous snakes and its bearing on the study of the venom delivery systems in snakes. Ph.D. Thesis, University of Kansas, Lawrence.

SAWAYA, R.J. 2004. História natural e ecologia das serpentes de Cerrado da região de Itirapina, SP. Tese de doutorado, Universidade Estadual de Campinas, Campinas.

SAWAYA, R.J. \& SAZIMA, I. 2003. A new species of Tantilla (Serpentes: Colubridae) from southeastern Brazil. Herpetologica 59(1): 119-126.

SAWAYA, R.J., SPINA, F., MONTEIRO, C., OLIVEIRA, J.L. \& BRASILEIRO, C.A. 2003a. Chironius flavolineatus (NCN). Predation. Herpetol. Rev. 34(4): 371-372.

SAWAYA, R.J., ARIEDI-JUNIOR, V.R., MONTEIRO, C. \& SPINA, F. 2003b. Oxyrhopus rhombifer (False Coral Snake). Predation. Herpetol. Rev. 34(4): 152-153.

SAZIMA, I. \& ABE, A.S. 1991. Habits of five Brazilian snakes with coralsnake pattern including a summary of defensive tactics. Stud. Neotrop. Fauna Environ. 26(3):159-164.

SAZIMA, I. \& HADDAD, C.F.B. 1992. Répteis da Serra do Japi: notas sobre história natural. In História natural da Serra do Japi: ecologia e preservação de uma área florestal no sudeste do Brasil (L.P.C. Morellato, ed.). Editora da Unicamp/FAPESP, São Paulo, p. 212-236.

SAZIMA, I \& MANZANI, P.R. 1995. As cobras que vivem numa reserva florestal urbana. In Ecologia e preservação de uma floresta tropical urbana Reserva de Santa Genebra (L.P.C. Morellato \& H.F. Leitão Filho, eds.). Universidade Estadual de Campinas, Campinas, p. 78-82.

SCOTT- JR, N.J., MAXWELL, T.C., THORNTON-JR, O.W., FITZGERALD, L.A. \& FLURY, J.W. 1989. Distribution habitat and future of Harter's Water Snake Nerodia harteri in Texas. J. Herpetol. 23(4): 373-389.

SNEATH, P.H.A. \& SOKAL, R.R. 1973. Numerical taxonomy. Freeman \& Co., San Francisco.

STRÜSSMANN, C. \& SAZIMA, I. 1993. The snake assemblage of the Pantanal at Poconé western Brazil: faunal composition and ecological summary. Stud. Neotrop. Fauna Environ. 28(3): 157-168.

STRÜSSMANN, C. 2000. Herpetofauna. In Fauna silvestre da região do Rio Manso, MT (C.J.R. Alho et al., orgs.). MMA/Edições IBAMA/ ELETRONORTE, Brasília, p. 153-189.

THOMAS, R.A. \& FERNANDES, R. 1996. The systematic status of Platyinion lividum Amaral, 1923 (Serpentes: Colubridae: Xenodontinae). Herpetologica 52(2):271-275.

VALDUJO, P.H. \& NOGUEIRA, C. 1999. Philodryas livida. Geographic Distribution. Herpetol. Rev. 30(1): 55-56.

VALDUJO, P.H., NOGUEIRA, C.C. \& MARTINS, M. 2002. Ecology of Bothrops neuwiedi pauloensis (Serpentes: Viperidae: Crotalinae) in the Brazilian Cerrado. J. Herpetol. 36(2): 169-176.

VANZOLINI, P.E. 1948. Notas sobre os ofídios e lagartos da Cachoeira de Emas no município de Pirassununga, Estado de São Paulo. Rev. Bras. Zool. 8(3): 377-400.

VANZOLINI, P.E. 1976. On the lizards of a Cerrado-caatinga contact Evolutionary and Zoogeographical implications (Sauria). Pap. Avulsos Zool. 29:111-119.

VANZOLINI, P.E. 1988. Distribution patterns of South American lizards. In Proceedings of a Workshop on Neotropical Distribution Patterns (P.E. Vanzolini \& W.R. Heyer, eds.). Academia Brasileira de Ciências, Rio de Janeiro, p.317-342.

VANZOLINI, P.E., RAMOS-COSTA, A.M.M. \& VITT, L.J. 1980. Répteis das Caatingas. Academia Brasileira de Ciências, Rio de Janeiro.

VITT, L.J. 1983. Ecology of an anuran-eating guild of terrestrial tropical snake. Herpetologica 39(1): 52-66. 
VITT, L.J. \& VANGILDER, L.D. 1983. Ecology of a snake community in northeastern Brazil. Amphibia-Reptilia 4(2-4):273-296.

WILSON, E.O. 1992. Estratégia de conservação de biodiversidade. In Estratégia global da diversidade: diretrizes de ação para estudar, salvar e usar de maneira sustentável e justa a riqueza biótica da Terra. Fundação O Boticário de Proteção à Natureza, Curitiba, p. 19-36.

WILSON, L.D. \& MENA, C.E. 1980. Systematics of the melanocephala group of the colubrid snake genus Tantilla. San Diego Soc. Nat. Hist. Memoir 11:1-58
ZAR, J.H. 1996. Biostatistical Analysis. Prentice-Hall, New Jersey.

ZIMMERMANN, B.L. \& RODRIGUES, M.T. 1990. Frogs Snakes and Lizards of the INPA/WWF reserves near Manaus Brazil. In Four Neotropical Rainforests (A.H. Gentry, ed.). Yale University Press, New Haven, p. 426-454.

Data Received 27/07/07 Revised 14/04/08 Accepted 28/04/08 